NBER WORKING PAPER SERIES

\title{
THE MARRIED WIDOW: \\ MARRIAGE PENALTIES MATTER!
}

\author{
Michael Baker \\ Emily Hanna \\ Jasmin Kantarevic \\ Working Paper 9782 \\ http://www.nber.org/papers/w9782
NATIONAL BUREAU OF ECONOMIC RESEARCH
1050 Massachusetts Avenue
Cambridge, MA 02138 \\ June 2003
}

We thank Stacy Dickert-Conlin for very helpful discussions and Dwayne Benjamin, Kevin Milligan, Marianne Page, Aloysius Siow, Frances Woolley and numerous seminar participants for comments. Much of this paper was completed while Baker held a F.H Gruen Distinguished Fellowship at the Australian National University. He thanks the Economics Program, Research School of Social Sciences at ANU for their hospitality and research support. He also gratefully acknowledges the funding of SSHRC (Grant \#410-990112). The views expressed herein are those of the authors and not necessarily those of the National Bureau of Economic Research.

(C2003 by Michael Baker, Emily Hanna, and Jasmin Kantarevic. All rights reserved. Short sections of text not to exceed two paragraphs, may be quoted without explicit permission provided that full credit including (C) notice, is given to the source. 
The Married Widow: Marriage Penalties Matter!

Michael Baker, Emily Hanna, and Jasmin Kantarevic

NBER Working Paper No. 9782

June 2003

JEL No. H2, H3, J1

\begin{abstract}
Marriage penalties are a controversial feature of many government policies. Empirical evidence of their behavioral effects is quite mixed. This is surprising because economic theory predicts that they should have an impact on the headship decision. We investigate the removal of marriage penalties from the surviving spouse pensions of the Canadian public pension system in the 1980s. These reforms provide a simple and transparent source of identification. Our results indicate that marriage penalties can have large and persistent effects on marriage decisions. We also present evidence suggesting that it is individuals with characteristics correlated with greater wealth who respond to the penalties.
\end{abstract}

Michael Baker

Department of Economics

University of Toronto

150 St. George St.

Toronto, ON M5S 3G7

and NBER

baker@chass.utoronto.ca
Emily Hanna

Department of Economics University of Toronto 150 St. George St. Toronto, ON M5S 3G7 ehanna@chass.utoronto.ca
Jasmin Kantarevic

Department of Economics

University of Toronto

150 St. George St.

Toronto, ON M5S 3G7

jkantare@chass.utoronto.ca 


\section{Introduction}

Subsidies or penalties for certain family structures are a feature of many government policies. These provisions attract spirited debate in both media and policy circles. Alm et al. (1999) argue that marriage penalties are viewed as not only violating principals of equity and efficiency, but also undermining the rule of law and family values. Few features of legislation enjoy such widespread notoriety.

Economists' primary interest is in the behavioural effects of these penalties. The reasons are standard efficiency concerns, as well as the ideal opportunity the penalties provide to test the widely accepted economic model of marriage (Becker 1973, 1974). This model predicts that relative economic opportunities, inside and outside marriage, are an input to the decision to wed. Marriage penalties/subsidies generate direct variation in income by an individual's marital state. An additional policy interest is the possible collateral effects of the penalties on health and longevity, as well as children's outcomes. For example, if marriage penalties promote out of wedlock births, or prevent widowed or divorced individuals from re-marrying, children will miss any developmental benefits that result from growing up with two, married adults instead of growing up with two, cohabiting adults or with a single adult.

Empirical evidence of the impact of marriage penalties challenges both our theoretical intuition and policy interest. Most studies indicate that the penalties have very modest effects. A number of explanations are offered for this anomaly. The structure of the penalties in, for example, the US welfare system makes identification problematic (e.g., Moffitt 1998). Alternatively, the variation in the penalties of the US federal tax code across individuals or regions or time is not very large (see, for example, Alm et al 1999). One might speculate that these problems mask substantial impacts of marriage penalties but there is little direct evidence 
that this is true. In another vein, new theoretical work explains how a strong link between marriage penalties and marriage and/or illegitimate births can be consistent with the small empirical estimates (e.g., Nechyba 2001).

In this paper we present direct evidence that marriage penalties can have large and persistent effects on marriage decisions. Our analysis exploits reforms that removed marriage penalties from the surviving spouse pensions of the Canadian public pension system in the 1980s. Prior to the reforms surviving spouses lost their pensions upon remarriage. A unique feature of the Canadian system is that there are two separate, but mostly identical, pension plans that cover individuals in different parts of the country. The Quebec Pension Plan (QPP) serves individuals working in Quebec, while the Canada Pension Plan (CPP) serves workers in other parts of the country. The marriage penalties were removed from the QPP in 1984 and from the CPP in 1987. The structure of the reforms allows us to avoid many of the perceived deficiencies of previous studies. More specifically, it offers: 1) simple identification-the temporal structure implies that as widows/widowers in one part of the country are affected by a reform, those in another part are not, 2) size - the marriage penalty is relatively large so that widows/widowers in most age groups experience an unambiguous reduction in financial welfare through remarriage before the reforms take place, 3) high treatment - the majority of prime age widows were in receipt of a survivor pension before the reforms took place, and 4) breadth - the group of individuals affected by the reforms spans a fairly large range of the age distribution, and a greater range of the income distribution than samples used in many past studies.

Trends in marriage rates by previous marital status, presented in figure 1, suggest these penalties had some effect. There is a significant negative trend in the marriage rate of each group throughout the period. There are distinct spikes in the remarriage rates of widows, 
however, in 1984 and 1987 when the marriage penalties were removed from the QPP and CPP, respectively. ${ }^{1}$ Furthermore, post 1987 there appears to be a trend break in the remarriage rates of widows relative to the rates of the other groups.

Using data from vital statistics, we confirm this inference documenting large and significant jumps in the remarriage rates of widows aged 15-59 and prime age widowers as the reforms take place. The identification of this result is transparent in graphs of the remarriage rates of widows and widowers by jurisdiction over the period, and the estimates are robust to a variety of checks for spurious inference. The impact of the penalties varies across age groups and jurisdictions in expected ways. Finally, we control for "stock" or "timing" effects that appear as spikes in remarriage rates in the years that the reforms took effect. Controlling for these spikes, a persistent, substantive effect of the penalties on marriage decisions remains.

Our estimates contrast with many in the literature. One explanation is the identification strategy we exploit coupled with the large values of the penalty and high levels of treatment. Another possibility is that many previous studies focus on the low-income population. We argue that many of the benefits of marriage over alternatives such as cohabitation have value to higher income individuals. This is because the benefits are typically legal rights to assets and income when the relationship ends, or to employment benefits associated with high paying jobs. Using data from the 1990 and 1995 General Social Surveys we investigate the characteristics of widows/widowers who remarried as the penalties were removed. We present evidence that suggests that individuals responding to the reforms possess characteristics associated with higher economic status relative to the mean in the pre-reform equilibrium.

\footnotetext{
${ }^{1}$ There is also a spike in the marriage rate of divorcees in 1987. This is due to the 1986 reforms of Canada's divorce law. The effect of these reforms is discussed below.
} 
While our primary contribution is new evidence that marriage penalties matter, the application to survivor pensions commands policy interest in its own right. Many survivor pensions incorporate marriage penalties either explicitly through a prohibition of remarriage, or implicitly through an income test applied at the household level. For example, the survivor benefits of the public pension plans of almost all countries of the European Union incorporate a full or partial penalty ${ }^{2}$, as do the benefits of the US Social Security system ${ }^{3}$. Our results provide direct evidence on the potential impact of these penalties on the remarriage decisions of beneficiaries.

\section{Previous Evidence}

The vast majority of previous evidence is studies of the marriage penalties in US federal laws, many of which are surveyed in Alm et al. (1999). One source is the penalties in the US federal tax code. The results indicate fairly small effects. ${ }^{4}$ For example, Alm and Whittingham (1999) estimate the elasticity of the probability of marriage with respect to the marriage penalty to be -0.23 for females and can't reject the hypothesis of no effect for males. One potential problem here is that the tax code is federal which makes identification difficult. Time series variation in the penalty due to changes in the tax law may be correlated with secular trends in family structure. There is also cross-section variation in the penalty-the penalty generally larger the greater the similarity of spouses' incomes—-but this may be correlated with heterogeneity in couples' decision-making processes, bargaining positions or preferences for marriage. In addition, as documented by Alm and Whittington (1996a), there are multiple, legitimate ways to calculate the penalty and the estimated penalties at the mean are not that large.

\footnotetext{
${ }^{2}$ See http://europa.eu.int/comm/employment_social/missoc2001/missoc_153 en.htm. The exception appears to be Denmark in cases in which the death occurred after June 30, 1992.

${ }^{3}$ See Brien et al (2000) for example.
} 
The other main source of evidence is the literature on welfare and marriage. There are numerous papers that explore the relationship between the incidence of marriage or single parenthood and the various income maintenance programs in the United States (i.e., AFDC). ${ }^{5}$ As noted by Moffitt (1998) in his survey of this literature, these studies provide conflicting signals, and "better" identification has not necessarily led to more confidence a relationship exists. Moffitt (1994) and Hoynes (1997) report that the penalties have little effect in studies that exploit time-series cross-section variation in welfare benefits and make proper allowance for state specific and individual specific fixed effects. Dooley et al (2001) make a very similar point using Canadian data. That said, Yelowitz (1998) reports some effect of headship incentives in the Medicaid program on marriage exploiting the expansions of the program in the 1980s and early 1990s for identification, and Grogger and Bronars (2001) document a relationship between welfare and marriage using a twins experiment.

In addition to concerns about identification, other factors hindering progress in this literature include low levels of treatment and a focus on the stocks of individuals in various marital states. For example, the proportion of individuals potentially affected by AFDC rules in analysis samples can be fairly low. ${ }^{6}$ Also, significant effects on flows out of single parenthood may build slowly over time in the stock, and therefore be lost in contemporaneous comparisons of changes in the stock to changes in marriage penalties. ${ }^{7}$

\footnotetext{
${ }^{4}$ Similar conclusions are offered in studies of marriage penalties and the decision to divorce (Whittington and Alm 1997 and Dickert-Conlin 1999).

${ }^{5}$ Recent research has investigated the marriage incentives of the TANF programs relative to this period (e.g., Bitler et al 2002).

${ }^{6}$ Moffitt (1992) reports AFDC participation rates of female heads with children of under 50 percent in the 1980s.

${ }^{7}$ Hoynes (1997) and Bitler et al. (2002) discuss the stock/flow issue in the context of the marriage penalties in the welfare system.
} 
There is evidence of more substantial impacts of tax provisions on the timing of marriage, divorce and births. ${ }^{8}$ Alm and Whittington (1996b) find that the size of the potential marriage penalty a couple faces has an effect on the decision to postpone marriage to the following tax year. Gelardi (1996) identifies a link between the timing of marriages within the year and tax provisions using time-series variation in the laws of Canada and the United Kingdom. Finally, Dickert-Conlin and Chandra (1999) provide evidence that the probability of a birth in the last week of the year (versus the first week of the following year) is related to child provisions in the US federal tax code.

One other paper, of interest here, is Brien et al's (2000) study of the marriage penalties in the US Social Security (SS) system. The authors exploit a change in the law in 1979, which removed a partial penalty for remarriage after age 60 . They document a dip in the marriage rate of widows at age 59 , and spike at age 60 , which becomes more pronounced in the post-1979 period. This strongly suggests that the SS marriage penalty affects the timing of marriage.

\section{Survivor's Benefits in the Canada and Quebec Pension Plans}

The CPP and QPP provide survivor benefits to widows and widowers (henceforth "widows"). To qualify, an individual must be the legal or common law spouse of the deceased. Separated legal spouses can also qualify for this benefit. ${ }^{9}$ The benefit is payable, regardless of the age of the deceased, as long as s/he made contributions to the Plans in one third of the calendar years in the contributory period (three year minimum) or 10 calendar years, whichever is less. The contributory period begins at age 18 (or January 1, 1966, whichever is later) and in the 1980s ends at age 65 (or death whichever is earlier). Prior to the reforms outlined below,

\footnotetext{
${ }^{8}$ There is a parallel here to the empirical tax literature. Auerbach and Slemrod (1997) argue that tax reform leads to a hierarchy of responses, ranging from first order effects on the timing of transactions to higher order effects on real decisions.
} 
benefit payment terminates if the surviving spouse remarries. Benefits are re-instated, however, if this subsequent marriage ends in divorce or the new spouse also dies. ${ }^{10}$

The benefits payable are based on the deceased's retirement pension, calculated at the time of death, but vary with the age and family circumstances of the surviving spouse. The formulas in the 1980s, prior to the reforms removing the marriage penalties, are as follows. If the surviving spouse is aged 65 or older, s/he would receive the greater of a) 37.5 percent of the deceased's retirement pension plus 100 percent of her or his own retirement pension, or b) 60 percent of the deceased's retirement pension plus 60 percent of her or his own retirement pension, with an upper cap equal to the maximum retirement pension payable in that year. If the surviving spouse is younger than 65 , and is disabled or has dependent children, the payment is 37.5 percent of the deceased's retirement pension plus a flat rate benefit which varies by year, and between the CPP and QPP programs. For surviving spouses younger than age 35, the payments only continue while the children are dependent: up to age 18, or age 25 if they are in school. Finally if the surviving spouse is younger than 65 and is not disabled or has no dependent children, the same formula is used except that the benefit is reduced by $1 / 120$ for each month the surviving spouse is younger than age 45 , so that no benefit is payable to individuals aged 35 or younger. ${ }^{11}$ There are also separate orphan's benefits for surviving dependent children.

The flat rate component of these benefits in the 1980s, payable to surviving spouses under age 65, is presented in table 1. Note that the rates are generally much higher in the QPP than the CPP. This difference between the CPP and QPP emerged in 1973 when the QPP rate

\footnotetext{
${ }^{9}$ Applications for survivors benefits can be rejected if death occurs within one year of marriage.

${ }^{10}$ In this latter case, the surviving spouse can collect survivor's benefits on the basis of any of her deceased spouses' records.

${ }^{11}$ Note, however, these excluded individuals are eligible for a survivor's benefits upon reaching age 65 .
} 
roughly tripled. Additional disparity between the two programs emerges in 1984 when a new higher rate is established for surviving spouses between the ages of 55 and 64 in the QPP.

More general information about the CPP and QPP is available elsewhere. ${ }^{12}$ Suffice it to say, it is a contributory public retirement and disability pension plan, financed by both employee and employer contributions. Retirement benefits are payable starting at age 65 at the beginning of the 1980s, although by the end of the 1980s benefit receipt can be initiated anytime between age 60 and 70 subject to an actuarial adjustment. While there are many similarities to the US SS system, a major point of difference is that the CPP/QPP programs pay out smaller benefits and, at least historically, have been financed by smaller payroll taxes. The maximum benefit in the 1980s averaged somewhat less than 25 percent of a moving average of the industrial aggregate wage. ${ }^{13}$ The smaller scale of the CPP/QPP is offset by three other Income Security (IS) programs for seniors: the Old Age Security (OAS) pension, the Guaranteed Income Supplement (GIS) and the Spouse's Allowance (SPA). In the period of study, the OAS is a benefit paid to all individuals aged 65 or older and is financed out of general tax revenues. The GIS is an income tested benefit again available at age 65 and financed out of general tax revenues. Finally, the Spouse's Allowance (SPA) is a program that allows individuals to collect OAS and GIS benefits as early as age 60 if they are married to someone aged 65 or older. ${ }^{14}$ In 1986, eligibility was extended to 60-64 year old widows creating a new, albeit transitory, marriage penalty for this group. ${ }^{15}$ To provide some context, in 1985 the maximum CPP/QPP benefit was $\$ 435.42$ per month, the OAS pension was $\$ 282.94$ per month and the maximum GIS available to a singles

\footnotetext{
${ }^{12}$ See for example, Burbidge (1987), Baker and Benjamin (1999) and CCH Canadian Ltd. (2000).

${ }^{13}$ The maximum now tracks exactly 25 percent of a moving average of the industrial aggregate wage.

${ }^{14}$ In this case the entire benefit (OAS plus GIS) is means tested, and at a higher rate. A more complete description of this program is contained in Baker (2002).

${ }^{15}$ Any effect of this marriage penalty should be absorbed in the estimating equation by common year effects. We discuss these effects below and in footnote 20 .
} 
was $\$ 338.95$ per month. In the Appendix, we present an overview of Canadian IS programs in the 1980 s.

\section{A Comparison to Survivors Benefits in other Countries}

The structure of the Canadian survivor benefits incorporates features that are present in whole or in part in the survivor benefits of public pension plans in other countries. For example, many plans condition benefit receipt for some widows on the presence of dependent children (e.g., Belgium, Netherlands, Norway, Portugal, Sweden, the United Kingdom and the US). In the absence of children, benefits in some plans are available only to older widows (e.g., France, Netherlands, the United Kingdom and the US) while others permit some (or all) childless, younger widows to benefit (e.g., Belgium, Denmark, Finland, Germany, Italy, Norway and Spain). Because we perform the analysis separately by age groups who face these different program rules, the results can potentially be informative for program design in these other countries.

\section{The Reforms of the CPP and QPP That Eliminated the Marriage Penalties}

In 1984, a package of reforms was introduced to the QPP that included the introduction of flexible retirement provisions permitting retirement benefit initiation anytime between ages 60 and 70 subject to an actuarial adjustment, as well as the reform of interest here, the elimination of re-marriage as a cause for the termination of survivor benefits. ${ }^{16}$ In addition, surviving spouses who had previously lost their benefits due to remarriage were eligible to have them reinstated with the passage of the law. Reforms of the CPP were made in 1987 that in many dimensions mirrored the 1984 reforms of the QPP. In particular they included the elimination of the

\footnotetext{
${ }^{16}$ This reform also included increasing in the flat-rate portion of disability benefits, providing disability pensions to individual aged 60 to 64 who are no longer able to carry on their current employment and raising the flat rate portion of the survivor benefit for surviving spouses aged 55 to 64 .
} 
marriage penalty for surviving spouses, and the reinstatement of benefits for those who had remarried previously. ${ }^{17} 18$

The political economy of these reforms is outlined in Baker and Benjamin (1999). They were mentioned periodically in the press and most of the coverage focused on the general level of benefits and solvency of the plans. Likewise, parliamentary discussion of the reforms focused on elements other than the elimination of the marriage penalties (e.g., Standing Committee on National Health and Welfare 1986). There is no evidence on record that the reforms were tailored to some well-known trend in the marriage behaviour of widows.

There is direct evidence, however, that widowed individuals were aware of the reforms. In figure 2 we graph the fiscal year over year growth rate of CPP/QPP survivor pension beneficiaries in Quebec and the ROC. There are spikes in the growth rates in each jurisdiction in the years corresponding to the relevant reforms. These would be due to applications for the reinstatement of benefits by individuals who had previously lost their benefits due to remarriage.

\section{The Predicted Effects of the Removal of the Marriage Penalties}

The elimination of the marriage penalty from the CPP and QPP raises non-labour income in the married state. The single state is unaffected as survivor benefits are available both pre and post reform. Therefore, "full income" in marriage increases both absolutely and relatively, which, all else equal, should raise the incentive to marry.

Some information on the size of the penalty and thereby the potential financial benefit from the reforms, is presented in tables 2 and 3 . In table 2 we report the average monthly

\footnotetext{
${ }^{17}$ They also included the introductory of flexible retirement provisions, the increase in the flat-rate portion of the disability benefit, changes to the minimum contributory period for disability benefits, an increase in the ceiling for combined survivor's and disability benefits, new rules for orphans benefits and new rules for splitting pension credits upon divorce or annulment.

${ }^{18}$ This sequence of reforms has been used previously by Baker and Benjamin (1999) to examine the impact of early retirement provisions on retirement behaviour and by Gruber (2000) to examine the effect of disability payments on labour supply.
} 
survivor pension in payment, by age and sex, in the month preceding the repeal of the marriage penalty from the QPP (December 1983) and CPP (December 1986), in year 2001 Canadian dollars. The differences by sex and age make sense given the benefit formulas. For example, the higher benefits for females under age 65 likely reflect the superior earnings histories of their (male) deceased spouses, which determine part of the benefit they receive. The sex difference is larger for 65-69 year olds, who also receive smaller benefits on average. There is no flat rate component for this group and so the deceased's earnings history plays a greater role. Finally, there are substantial differences in benefits across jurisdictions for individuals under age 65 . One source of this disparity is the higher flat rate benefits for these individuals in the QPP (table 1).

An estimate of the average size of the marriage penalties is presented in table 3 . We calculate the present value (2001 CDN dollars) of the average survivor pension taken from table 2 at selected ages. This is the amount of benefits widows give up on remarriage. We discount future benefit receipt by sex specific survival probabilities (Statistics Canada 1984), and assume a real interest rate of 3 percent. We also assume that benefits remain constant in real terms in the future, which is consistent with the indexing provisions of the CPP and QPP. Finally, for the estimates at age 30 we assume the widow has one child, aged 5, who will not remain in school past age 18. Therefore, the survivor benefits are received for the next 13 years. ${ }^{19}$

The estimated costs are not trivial for prime aged females, ranging from $\$ 75,000$ to $\$ 130,000$. The sex differences evident in table 2 are preserved here as the base differences in monthly benefits are accentuated by sex differences in longevity. Therefore, females in receipt of a pension face a larger penalty and thus disincentive to marry. The penalty is also clearly

\footnotetext{
${ }^{19}$ The estimates for this age can vary substantially depending on the assumptions made about any dependent children. For example the present value of the penalty is as high as $\$ 97,000$ for females if we assume the child is currently 1 year old and remains in school until age 25 .
} 
larger for individuals under age 65 in Quebec. Finally, the penalty is similar across jurisdictions and quite small for individuals aged 65 or older.

We have also calculated a more complex accounting of the full IS cost of remarriage prior to the reforms. ${ }^{20}$ The "marriage penalty" is defined as the difference between the present discounted value of IS benefits flowing to the widow if $\mathrm{s} / \mathrm{he}$ remains single and the value if $\mathrm{s} / \mathrm{he}$ remarries. The results of this exercise (available on request) are consistent with the story told by table 3. In particular, the magnitudes are very similar reflecting the fact the greater part of the IS marriage penalty is the loss of the surviving spouse pension captured in table 3 . The one difference is the penalties are larger in the rest of Canada (ROC) reflecting the additional marriage penalty imposed by the extension of the SPA to widows mentioned above.

An estimate of the incidence of the penalties - the proportion of widows or widowers in receipt of surviving spouse's pensions - in the years preceding the two reforms is presented in table 4. These are calculated from administrative data on the number of CPP or QPP survivor pensions in payment by age and estimates of the population of widows of that age taken from Statistics Canada's CANSIM database. Receipt is clearly higher for females than for males and would appear to decline with age. The relationship with age may be cohort effects, however, as the CPP/QPP system was initiated in 1966, so the deceased spouses of some of the oldest

\footnotetext{
${ }^{20}$ We take account of the sum of CPP/QPP survivor pensions, CPP/QPP retirement pensions, as well as OAS, GIS and SPA benefits received in the married versus single states, accounting for any effects of marital status on the benefits received from these programs (through means testing on family income - see the Appendix). The flows are defined by the benefits flowing directly to the widow. We therefore assume there is no sharing in the married state. Additional inputs to this calculation include the amount of the retirement pension or non pension income any new spouse brings into a marriage, as well as the non-pension income of the widow (note for these calculations we must make assumptions about the age and economic circumstances of any new spouse. We also take account of a reform of the SPA in 1986 that extended benefits to widows who had not remarried. This added another marriage penalty for widows in the two jurisdictions, although only in a present value sense for those under age 60 . Note that this second marriage penalty is not necessarily severe for widowed females. By remarrying they lose access to the widow benefits of the SPA starting at age 60. Assuming that they marry someone older, however, as is typical, they will qualify for SPA benefits under its original provisions sometime between age 60 and 64 . For example if their new spouse is 3 years older they would qualify for the SPA starting at age 62-a two year difference from the age they qualify as a widow.
} 
individuals in these years may have had very little participation in the program. The lower receipt rate for males likely reflects the fact that females have lower labor market participation rates, and therefore are less likely to have a CPP/QPP earnings history to generate a benefit for their surviving spouses. The rates are also marginally higher in the ROC than in Quebec, but this is to be expected since incidence is growing over time and the ROC data are from a later period.

\section{Data}

The main variable of interest is the remarriage rate of widowed females and males, by province, over the period. The numerator of this rate is constructed from special tabulations from the vital statistics marriage file maintained by Statistics Canada. This file contains the information on marriage certificates for all marriages occurring within a given year. Each marriage certificate provides information on the age of the bride, the age of the groom, the previous marital status of the bride and the previous marital status of groom, and the year and province of marriage. The ages of the bride and groom are reported in five-year intervals, with 15 age intervals in total. Previous marital statuses are single, divorced and widowed. Grouping these data within Quebec and by province within the ROC, and within the age groups specified below, we divide the number of widows or widowers remarrying in a given year by the corresponding stock of widows or widowers in these same geographic/age cells, which are available through the Statistics Canada CANSIM database. We construct these rates for the period 1975 through 1995 inclusive.

A key advantage of these data is that we can analyze flows into marriage by previous marital state. This is exactly the information we need to examine the impact of the reforms. Many previous studies examine the stock of individuals in a given marital state. The effects of marriage penalties may only manifest in the stock over time. A weakness is that there little 
additional information on the widows. Therefore we do not know the magnitude of the survivor benefits they were entitled to or much about their demographic and economic characteristics.

\section{An Overview of the Empirical Strategy and Identification}

We estimate changes in the remarriage rates of widowed females and males in Quebec (the ROC) as the marriage penalty is removed, using the rates in the ROC (Quebec) as a control. The estimating equation is

$$
\begin{aligned}
R M R_{i t}= & \beta_{0}+\beta_{1} Q U_{i}+\beta_{2} R E F 84_{t}+\beta_{3} Q U_{i} \cdot R E F 84_{t}+\beta_{4} R E F 87_{t}+ \\
& \beta_{5} Q U_{i} \cdot R E F 87_{t}+\eta X_{i t}+\varepsilon_{i t}
\end{aligned}
$$

where $i$ indexes provinces, $t$ indexes time, $Q U_{t}$ is a dummy variable for Quebec, $R E F 84_{t}$ is a dummy variable for the years 1984 and after, $R E F 87_{t}$ is a dummy variable for the years 1987 and after and $X_{i t}$ is a vector of other control variables. The parameters $\beta_{3}$ and $\beta_{5}$ capture the relative difference in the change in remarriage rates, $R M R_{i t}$, in Quebec and the ROC as the reforms take place. A priori, we expect $\beta_{3}$ to be positive and $\beta_{5}$ to be negative if the removal of the marriage penalty encouraged remarriage among widows.

The equation is estimated separately for males and females, and for the age groups $<35$, $35-44,45-59,60-64$ and $65+$. One reason for the age splits is that preferences and/or opportunities for marriage may vary systematically with age due to, for example, fertility or cohort effects. A second is that the formula for calculating survivor benefits makes distinctions by many of these age groupings. For example, survivor benefits are reduced for childless surviving spouses between the ages of 35 and 44 . Finally, changes in other marriage penalties over the period directly affect specific age groups. For example, after 1986 the widowed SPA has immediate consequences for those aged 60 to 64 . 
The control variables, $X_{i t}$, are province and year effects and measures of marriage market conditions. The latter are estimates of the ratio of unmarried females to unmarried males in the age groupings listed above constructed from Statistics Canada CANSIM database. ${ }^{21}$

Equation (1) is estimated by weighted least squares using the number of widows in the corresponding province/age group cell as weights. Standard errors are corrected for heteroskedasticity. Estimates of the first through third order autocorrelation parameters of the residuals were calculated, and indicate autocorrelation is not a significant problem in this instance. $^{22}$ Finally, while the linear specification in (1) facilitates comparisons of the estimates to graphical evidence of changes in $R M R_{i t}$ over the period, it does not obey the restriction $0 \leq R M R_{i t} \leq 1$. We have estimated a logistic specification of $R M R_{i t}$ by non-linear least-squares and both the magnitudes and statistical significance of the estimated parameters are in agreement with the results presented below. ${ }^{23}$

The assumptions for identification in this framework are now well known. In addition to the linear functional form, any time trends must be common to both groups and there can be no jurisdiction specific shock coincident with the reform. Furthermore, in the absence of an assumption of a homogeneous treatment effect, we estimate the average effect of the marriage penalty on remarriage for individuals whose marriage decision is affected by the remarriage provisions of the CPP and QPP.

\footnotetext{
${ }^{21}$ While the age groupings are not necessarily appropriate delineations for marriage market opportunities, the estimates of $\beta_{3}$ and $\beta_{5}$ are not overly sensitive on this margin. For example, the results are very similar if we only include the sex ratio for the age group that the dependent variable (marriage rate) is defined for.

${ }^{22}$ The parameters are estimated by regressions of the current residual on the relevant lagged residual, pooling the data across provinces. The estimates are almost always small ( 0.2 or less) and statistically insignificant for both males and females (largest estimate is -0.32). Even accounting for the probable bias of estimating these parameters from a short panel (Solon 1984), they provide little evidence of substantive autocorrelation.

${ }^{23}$ Where there are disagreements, the estimates from the non-linear model indicate larger effects of the reforms.
} 
One change in the marriage market over the sample period is the 1986 reform of the divorce act. This reform removed the requirement of fault as grounds for divorce. Corak (2001) presents evidence of a transitory dip and spike in the aggregate divorce rate around 1986, as some individuals delayed seeking a divorce until the new law came into place. A corresponding dip and spike in the remarriage rate of divorcees can be seen around this time in figure 1 . To the extent that these divorced individuals remarried widows the widowed population becomes indirectly treated by the change in the divorce act.

We perform three checks for these sorts of effects or other jurisdiction specific trends that may bias our inference. First, we examine the time series of remarriage rates in the two jurisdictions in the period proceeding our sample period. Second, we estimate variants of equation (1) that include province specific linear or quadratic trends. Third, we use, alternatively the marriage rates of singles and divorcees in the corresponding age groups to form a triple difference estimator. ${ }^{24}$

\section{An Overview of the Data}

In table 5 we present an overview of widows and widowers in Quebec and the ROC, prior to the reforms, using 1981 Canadian census data. There are many similarities between these groups in the two jurisdictions. Widows in the ROC are more likely to work, however, and their educational attainment is higher, although the latter point may be partly semantic as there are fundamental differences in the structure of education in the two jurisdictions.

\footnotetext{
${ }^{24} \mathrm{We}$ also investigated the possibility of using the remarriage rates of American widows and widowers as an additional control. Vital statistics on the remarriages of widows and widowers are available for a subset of states over our sample period. To calculate remarriage rates we constructed estimates of the eligible population of widows and widowers in these states using CPS data. Unfortunately these estimates are very noisy, such that the majority of the variation of the constructed remarriage rates is attributable to variation in its denominator. Since our analysis depends on identifying "jumps" in remarriage rates, and we have little reason to believe that the population of widows or widowers would display such behaviour, this line of inquiry was abandoned.
} 
Table 5 also reports the proportions who migrated from Quebec to the ROC, or vice versa, over the preceding 5 years. An implicit assumption of the analysis is that widows in a given jurisdiction are not indirectly treated by the reform in the other jurisdiction. This assumption would clearly be false if all widows in Canada are in the same marriage market. To directly test this hypothesis would require the migration rates of the married population by (previous) marital status in the origin province, or marriage rates by the previous residence of the spouses. This information is not available. Therefore, the fact that table 5 reveals very little inter-jurisdictional migration by widowed males and females over the past five years is supportive of the assumption but not definitive. More generally, Quebecers are much less likely to make cross-provincial moves than English Canadians. Among widowed females (males) in the ROC, 2.4 (2.4) percent reported moving across province in the previous 5 years versus 0.4 (0.4) percent of those in Quebec. ${ }^{25}$ For the entire female (male) population, aged $16+$, the rates are $6.3(6.9)$ percent for those in the ROC and just 1.0 (1.0) for those in Quebec. ${ }^{26}$ These ROC/Quebec differences likely reflect the underlying differences in language and culture between the two parts of the country.

Our first check for jurisdiction specific trends is presented in figure 3 where we graph the remarriage rates of widowed females and males in the two jurisdictions between 1956 and 1975. Since annual population by marital status is not available for this period, we use total population in the denominator to calculate these rates. For females, the trends in Quebec and the ROC appear identical, the levels differing by a constant. This is confirmed in regressions of the difference in remarriage rates on a constant and up to a quintic in time: the estimates of the parameters of the polynomial are consistently small and both individually and jointly statistically

\footnotetext{
${ }^{25}$ Note that inter-jurisdictional and inter-provincial migration are the same for individuals in Quebec.

${ }^{26}$ In the underlying samples Quebecers made up 27 percent of the male and female samples.
} 
insignificant. For males there are some differences in the time series, although primarily in the first part of the period. This is confirmed in the regressions, as the parameters of the polynomial are jointly significant using the full sample, but not when we delete the data from the 1950s.

In figures 4 and 5 we graph remarriage rates, by age, of widowed females and males in the two jurisdictions over the sample period. These are the dependent variables for our regressions. In figure 4 there is evidence of a downward trend in the marriage rates of all females over the period. There is also clear sequential evidence of an effect of the QPP and CPP reforms for females aged 15 through 59. For example, the remarriage rate of females aged 45-59 jumps up in Quebec in 1984 as the marriage penalty is removed from the QPP. A corresponding jump is visible in the remarriage rate in the ROC in 1987 as the penalty is removed from the CPP. In succeeding years the marriage rates in both jurisdictions continue to decline, but from a new higher base. In each case there is also evidence of spikes in the exact years of the reforms. These are consistent with either timing effects—some individuals postponing their marriages once the reforms were made public — or with stock effects—-there was a stock of widows who did not marry due to the penalty, who then married as soon as the reform became law. Timing effects may be the less likely explanation as benefits were reinstated for all widows who had remarried once the rules changed. The elevated levels of the rates that persist after the spikes, however, suggest that the marriage penalties had a longer term effect on marriage activity.

The evidence for females aged $60+$ is not as conclusive. For females aged 60 to 64 there are spikes in the years of the reforms, but less evidence of elevated remarriage rates thereafter. The remarriage rates of those 65 and older display little correspondence with the reforms.

One might be tempted to relate the Quebec/ROC differences in the remarriage rates by age group to the information in table 3: remarriage rates are lower in Quebec because the 
marriage penalties are larger, and the differential declines with age in tandem with the differential in the penalty. While the inter-jurisdictional difference in the marriage penalties may contribute to the corresponding difference in marriage rates it cannot be the only cause. Single and divorced Quebecers also have lower marriage rates than their counterparts in the ROC. ${ }^{27}$ Therefore, some part of the ROC/Quebec differential in the remarriage rates for widows in this period should be attributable to a common, lower propensity for marriage in Quebec, rather than a marriage penalty differential per se. This is a graphic example of the potential biases in cross section evidence of the relationship between marriage penalties and marriage rates.

The graphs for widowed males aged 45-59,60-64 and 65+ (figure 5) are similar to the graphs for their female counterparts. There is clear evidence of a persistent effect of the reform for those 45-59, some evidence of a transitory effect (i.e., spikes) for those 60-64, and little evidence of any effect for those $65+$.

In contrast, the graphs for the youngest males paint a confusing picture. While there are spikes in the expected years, there are also spikes in the Quebec rates in the years between 1986 and 1989. Graphs of the numerator of the these remarriage rates reveal dramatic increases (200 to 300 percent) in the number of widowers remarrying at these ages in these years, followed by offsetting dramatic decreases. One possible source of this activity are the previously mentioned reforms of Canada's divorce laws that led to a transitory surge in the remarriages of divorces starting in 1987 (figure 1). If female divorcees primarily married widowed males, this could account for the pattern in remarriage we see in figure 5. If this were true, however, we would expect to see corresponding jumps in remarriage in the ROC as divorce reforms affected all parts

\footnotetext{
${ }^{27}$ For example, the remarriage rate of widowed females, aged 45-59, averaged 0.93 percentage points or 105 percent higher in the ROC than in Quebec over the period 1975-1983. Over the same period, the marriage rate of 45-59 year old singles averaged 0.36 percentage points or 54 percent higher in the ROC. Finally, for divorced females in this age group the marriage rate averaged 2.2 percentage points or 72 percent higher!
} 
of the country. Also, examination of the disaggregate data reveals the surge in marriages is through unions with single females. The other possibility is some sort of coding error. We have contacted Statistics Canada about this hypothesis but they report no obvious problem with the data. As we cannot confirm an explanation of these patterns in the data, we report results for these age groups but we focus on the estimates for the older males. ${ }^{28}$

\section{Estimates of the Effect of the QPP and CPP Marriage Penalties}

Estimates of equation (1) are reported in the first panel of table 6. The results for widowed females are strongly consistent with the story told in figure 4. For females under the age of 60 , there is a clear evidence of a statistically significant and almost symmetric effect of the reforms on the remarriage rates in Quebec and the ROC. There is also evidence of a statistically significant effect for females aged 60 to 64 , although in this case it is almost double the size in the ROC. Finally, there is little evidence of an effect of the reform for females aged $65+$. In each of these cases the regression results display a remarkable congruency with the evidence in figure 4, highlighting the transparency of the identification.

To provide an indication of the economic significance of the results we normalize the estimated increase in the remarriage rates by the average rate in the three years preceding the reforms (1981-83 for Quebec and 1984-1986 for the ROC). The results are reported in the square brackets in table 6 . These calculations highlight the lower base remarriage rates in Quebec. For example, the estimated increase of 0.013 for females aged 35-44 in Quebec is from a base of 0.013 in 1981-1983. Therefore, the remarriage rate effectively doubles for this group. The jump of 0.009 for females of this age in the ROC is from a higher base of 0.038 in 19841986 implying a much smaller 24 percent increase. More generally, for females under the age of

\footnotetext{
${ }^{28}$ Another explanation is that these remarriage rates are based on the smallest cell sizes observed, often fewer than 40 or 50 individuals. That said, if this were measurement error we would expect a less systematic pattern, which is
} 
65 the removal of the marriage penalty increased the remarriage rates between 24 and 100 percent.

In the second panel, we present a set of estimates that attempt to net out any timing or stock effects of the reforms - the spikes in 1984 and 1987. We add an interaction between the Quebec dummy variable and year effects for 1984 and 1987 in (1). These should absorb any extra jump in the rates in these years. The result for females aged 15-59 is modest decreases in the estimated effect of the penalty that preserve the relative magnitudes across jurisdictions. The estimates continue to imply sizable increases in remarriage rates ranging from 21 to 108 percent.

The results for widowed males are presented in the second half of each panel. Given the vagaries of the data for younger widowers from Quebec, we focus on the results for those 45 years and older. The patterns of statistical significance of the parameter estimates are very similar to the results for females. Significant effects are found for males aged 45-59. Widowed males have higher remarriage rates than widowed females, so the larger point estimates for this group do not imply larger proportional effects. The proportionate responses to the reforms in the first panel are 55 percent in Quebec and 22 percent in the ROC. Netting out timing or stock effects (panel 2) results in very marginal changes. The estimates for males 60-64 and 65+ are small, sometimes wrong signed, often statistically insignificant, and sensitive to specification.

The final two checks for jurisdiction specific trends are reported in tables A2 through A4 of the Appendix. Table A2 contains estimates when we add province specific quadratic trends (results for linear trends are very similar and available on request). For widows aged 15-59 and widowers aged 45-59 the estimates are very robust to this innovation. Tables A3 and A4 contain the triple difference estimates using singles and divorcees, respectively, as additional controls. Most of the results are again very similar to those in table 6 for the age groups of interest. The 
exceptions are the estimates for the youngest females in the ROC, especially when the divorcees are used as a control. Because of the reform of the divorce laws almost corresponds with the 1987 reform of the CPP, it not clear the much larger estimates for widows aged 15 through 35 in Table A4 deserve much weight. ${ }^{29}$

A consistent result for both females and males is that the estimated effect of the penalties is larger in the province of Quebec. An explanation of this result is that marriage penalties are much larger for prime aged males and females in this province (tables 1 through 3 ). In the top panel of figure 6 we plot the responses of widows aged 15-64 and widowers age 45-64 from the top panel of table 6 against the estimated marriage penalty for each group from table 3 . We also plot the predicted values of a simple linear regression of the responses on the penalties. The relationship between the responses and penalties is positive: the slope of the regression line is 2.16e-06 with a t-value of 3.60 .

In the second panel of figure 6 we attempt to account for the differences in "treatment" across widows and widowers of different ages documented in table 4 . If we assume the reforms have no effect on widows and widowers who are not receiving a survivor pension, we can divide the estimated behavioral response for each group by the proportion of the group that is receiving a pension. ${ }^{30}$ The figure in the second panel uses the proportions from 1983 and 1986. The slope of the regression line is now $4.91 \mathrm{e}-06$ with a t-value of 2.47 , again confirming the inference.

\section{Context and Interpretation}

Our estimates contrast with many in the literature. To draw comparisons we focus on previous studies that also use a time series-cross section empirical framework. Moffitt (1998)

\footnotetext{
${ }^{29}$ An explanation of the smaller estimates for these age groups in table A3 is that singles are the most common partners of young widows who remarry.
} 
identifies three studies examining the relationship between state level welfare benefits and marriage or female headship in the US using this approach. Direct comparison is complicated because each of these studies examines the effects of the welfare system's marriage penalty on net changes in the stock of female heads, while the focus here is on gross flows into the married state. Furthermore, the stock of female headship is the result of both a fertility decision of single females and a union decision of parents. That said, in two cases, Moffitt (1994) and Hoynes (1997), the authors report no effect of the marriage penalties on the behavior of white females. Moffitt (1994) finds some effect for African American females, although the evidence from Hoynes (1997) suggests that this may result from his inability to control for individual fixed effects. Lichter et al (1997), however, report statistically significant effects of these marriage penalties using county level data from the 1980 and 1990 US censuses. A $\$ 100$ increase in welfare benefits leads to a 0.838 percentage point increase in the county female headship rate. Given the "long changes" (10 years) used to identify the behavioral effect, it seems plausible that some part of the estimated response could due to migratory responses to benefit differentials (Moffitt 1998). ${ }^{31}$ Also, a recent study of the 1970, 1980 and 1990 census data reports no effect of welfare benefits on female headship in a model including MSA level fixed effects and time trends (Blau et al 2002).

Grogger and Bronars (2001) study the impact of welfare based marriage penalties on the flow into married state, modeled as a hazard. Their identification strategy exploits variation in marriage penalties induced by twin births. Their sample is unwed mothers who have had one

\footnotetext{
30 This assumption will be incorrect if treated widows and widowers remarry untreated widowers and widows. Across all sample years just under 10 percent of widows/widowers aged 20-29 remarried other widowers/widows. This proportion rises to roughly 37 percent for those aged 50-59.

${ }^{31}$ Also, the estimates of the standard errors in this study are potentially biased by "group effects", as the welfare benefit variables are defined at the state level while the dependent variable is defined at the county level. The reported behavioral response has a t-value of 3.92 (Lichter et al 1997, table 3 column 3).
} 
birth, and the hazard is defined in terms of duration from this first birth to marriage. The results indicate that a 10 percent decrease in welfare benefits leads to a 5.7 percent increase in the percentage of white females married after 1 year and a 3.5 percent increase after 5 years. The estimated responses for African American females are not statistically significant.

Given differences in samples and dependent variables across these studies, a qualitative rather than quantitative comparison of results is probably the most useful. In the current case the reduction in the marriages penalty was 100 percent, so the estimated percentage changes in marriage rates in table 6 (square brackets) can be interpreted directly as (discrete) elasticities. For prime age female widows these estimates are closer to one than to zero. Furthermore, if we adjust them for the fact that less than 100 percent of widows in any age groups were in receipt of a survivor pension (as in figure 6), the estimates for both prime age females and male widows would be greater than one. In contrast, most existing time series-cross section estimates are of a zero or at best a fairly inelastic response. ${ }^{32}$

What leads to this difference in results? One possibility is the identification strategy used here combined with the magnitude of the marriage penalties we analyze. Another is the higher level of "treatment". In most age groups more than 60 percent of widowed females were in receipt of a survivor pension at the time of the reforms. Although the samples used in previous studies differ, the percentage of females potentially affected by AFDC regulations would presumably be lower in many instances. That said, the proportion of widowed males aged 45-49 in receipt of a survivor pension is only about one-third (table 4), and we find evidence that the marriage penalties had a substantive effect on their behavior.

\footnotetext{
${ }^{32}$ We are not aware of any time series-cross section studies of marriage penalties in income tax systems for comparison. For example, Alm and Whittington (1999) use panel data, but exploit both the time series and cross individual variation in the estimation because they do not include individual level fixed effects.
} 
Still another explanation is our focus on the gross flows of individuals into the married state, rather than net changes in the stock of individuals who are widows. Changes in marriage penalties will affect gross flows more quickly than stocks, particularly when the absolute levels of the flows are small. Small flows and/or a low baseline incidence of the marital state of interest can preclude precise identification of stock effects given the sample sizes of popular data sets. These considerations are clearly important here. The age groups with the highest remarriage rates have the lowest incidence of widowhood and vice versa. In table 7 we report estimates of equation (1) when the dependent variable is a $0 / 1$ indicator that an individual is widowed. We use the 1976-1995 Labor Force Surveys (LFS), sampling all males or females of all marital statuses in the indicated age categories. ${ }^{33}$ Given the results in table 6 , we expect $\beta_{3}$ to be negative and $\beta_{5}$ to be positive in these results. The estimates indicate no systematic effects of the marriage penalties on the stock of widows, as almost all the estimated parameters are statistically insignificant. The sample sizes for these regressions are between 125,000 and $1,000,000$ observations.

Finally, our analysis focuses on a different part of the population. Many previous studies analyze penalties that affect beneficiaries of income-tested programs. Marriage penalties in the US federal income tax system affect a wider segment of the population, but financially are rather modest.

What might this matter? Some would argue that the focus in previous studies is ideal. Marriage penalties impose a larger proportionate cost on low-income individuals. That said, the benefits of marriage for these same individuals may be very small. This is because the alternative of co-habitation, which offers many of the traditional benefits of marriage such as

\footnotetext{
${ }^{33}$ We use the April and October samples in each year to ensure no repeated observations on individuals. There is no
} 
companionship and economies of scale in household production, is growing in acceptance and popularity. In fact, this alternative is relatively common within the low-income population (Moffitt et al 1998).

Admittedly, co-habitation is an imperfect substitute for marriage. For example, cohabiting relationships are less stable (Bumpass and Lu 2000). ${ }^{34}$ Also, because of the explicit contract that it provides, marriage confers a different set of rights and obligations on the parties. Cohabiting partners are often denied the rights of spouses in government and private sector income support, benefit and retirement programs, although this differential treatment is disappearing in many developed economies. Cohabitants and spouses can also find themselves in different positions if the relationship ends either through separation/divorce or the death of a partner.

There are specific differences in these rights in Canada (see Holland 1990). For example, in most provinces cohabitants do not have occupational rights in the family home and all provinces exclude them from intestacy provisions. During the 1980 s cohabitants were not equivalent to spouses for the purposes of the Income Tax Act. ${ }^{35}$ This meant that cohabitants were not eligible for, among other things, the spouse deduction and could not contribute to their partner's Registered Retirement Savings Plans (RRSP's, a tax subsidized retirement savings plan) as married partners could. ${ }^{36}$ Property rights upon dissolution of the relationship have different bases in law. For married individuals the basis is matrimonial property legislation under which both spouses are assumed to have contributed equally to the marriage and so the

public use data for the 1975 LFS. The LFS is similar to the US Current Population Survey.

${ }^{34}$ Recent research on cohabitation includes Moffitt, Reville and Winkler (1998) and Bumpass and Lu (2000) and the references therein.

${ }^{35}$ Under revisions made in the 1990s, co-habitants and spouses are now treated the same for this purpose.

${ }^{36}$ The incentive to contribute to the partner's RRSP is income splitting on retirement to minimize tax payments. Canada has an individual based tax system. 
default is an equal division of family property. Also, assets are broadly interpreted to include family property, business property, pensions rights and even increases in the value of assets acquired prior to marriage. In contrast, property rights for cohabitants are founded on the principle of "unjust enrichment", and so the onus is on the litigant to prove the defendant has been unjustly enriched. Furthermore, cases are typically restricted exclusively to family property.

If these are the primary benefits of marriage relative to cohabitation, it might be expected that cohabitation is more common in the low-income population. These benefits have value in relationships where there are income and assets at state. Accentuating this effect are rules limiting partner benefits in government and private benefit plans to married individuals. These rights will have value to individuals in well paying, stable jobs.

Are these considerations relevant here? One possibility is the CPP/QPP marriage penalties prevented unattached widows from participating in the marriage market. Once removed, these individuals re-entered the market and found mates. While this explanation may played some role in the new long run steady state, if marriage search takes time it is unlikely these types of people contributed to the initial response. More likely it was individuals who had identified partners, and were perhaps cohabiting with them, that made up the initial wave of remarriages. ${ }^{37}$

We investigate this issue using data from the 1990 and 1995 General Social Surveys (GSS). The GSS is an annual, nationally representative survey of the Canadian population that focuses on different social issues. The 1990 and 1995 surveys contain information to construct the marriage histories of respondents extending back three marriages. This allows us to view the

\footnotetext{
${ }^{37}$ The law only mentions marriage and not cohabitation as a reason for termination of survivor benefits. That said, one might imagine that in practice cohabitation was treated symmetrically to marriage for this purpose. Discussions with individuals at Human Resources Development Canada suggest there was no program of enforcement of such an
} 
marriage behavior of widowed individuals over the period the reforms took place. The number of widowed individuals captured in these data is small, however, so our analysis must necessarily be exploratory and speculative.

We select individuals who had a marriage end by the death of their spouse. We require that the deceased spouse could potentially have contributed to the CPP/QPP for at least 5 years to ensure that there is a survivor pension at stake. This produces a sample of 2179 individuals, 1723 of whom are females. Some summary statistics are reported in the top panel of table 8 . Two notable characteristics are the rather low level of completed education of the sample and the cumulative remarriage rate of 12 percent.

Most of the characteristics of the individuals captured in the GSS are for the survey date, which is January through March 1990 or January through December 1995. Since we are interested in the characteristics of these individuals at the time of any remarriage, we focus on attributes that are unlikely to change considerably over time. We investigate $0 / 1$ indicators of educational attainment, and home ownership as a proxy for wealth. We also examine an indicator of whether any remarriage was preceded by cohabitation. These characteristics are used as dependent variables in the equation

$$
Y_{i t}=\alpha_{0}+\alpha_{1} Q U_{i t}+\alpha_{3} Q U_{i t} \cdot R E M 84_{i t}+\alpha_{5} Q U_{i t} \cdot R E M 87_{i t}+\lambda t+\phi X_{i t}+v_{i t}
$$

where $Y_{i t}$ is the binary variable for individuals' education, home ownership or cohabitation, REM84 and REM87 are dummy variables that equal one if the individual remarries respectively, in 1984 or 1987 (or later), $t$ is a dummy variable equal to 1 for observations from the 1995 survey, and $X_{i t}$ is a vector of other control variables: quartics in the individual's age and their age when their spouse died, a quartic in the year their spouse died, a quartic in the year of 
any remarriage, and dummy variables for females and individuals who remarry. ${ }^{38}$ This equation has a similar structure to (1), with $\alpha_{3}$ and $\alpha_{5}$ playing analogous roles to $\beta_{3}$ and $\beta_{5}$. The main difference is that time (and age) effects are modeled as quartics rather than unrestricted dummy variables as a concession to the small sample size. ${ }^{39}$ All estimation is by weighted least-squares using GSS sample weights and standard errors are corrected for heteroskedasticity.

The regression results are reported in the lower panels of table 8. We report estimates for both the full sample and the smaller sample of widows. In the first four rows we examine measures of educational attainment. In either sample the signs of the estimates indicate a relative increase in the educational attainment of individuals marrying after the removal of the marriage penalty in the QPP, which is subsequently offset as the penalty is removed from the CPP. Note, that the only statistically significant estimates are from the sample of widows. The signs of the estimates for home ownership, as a proxy for wealth, indicate greater resources among those marrying post reform. Finally, the signs of the estimates in the sixth row of each panel indicate that the post reform remarriages were more likely to be preceded by cohabitation.

These results provide some evidence, therefore, that it was more educated and wealthier individuals who responded to the removal of the marriage penalties. This is consistent with the hypothesis that there are very small incremental benefits of marriage over cohabitation for the low-income population. There is also evidence that cohabitation prior to remarriage was more likely after the reforms. That said, the results are based on small samples and many of the point estimates are not statistically significant.

income tax act of this time, there were few alternative administrative methods to identify this state.

${ }^{38} \mathrm{We}$ have also estimated specifications that include interactions between the remarriage dummy and the quartics in age at spouse's death and the year the spouse died. These interaction terms are typically jointly insignificant, and the effect of this change in specification on the parameters of interest is negligible.

${ }^{39}$ We have replicated the analysis using this alternative specification and retrieved point estimates that are qualitatively similar to those reported below. 


\section{Conclusions}

Marriage penalties are a controversial feature of many government programs. While they may be found deficient in a variety of dimensions, the evidence that they cause behavioural distortions is quite mixed. This is surprising because economic theory predicts that these penalties provide a clear incentive to remain single (or cohabitate). In this paper we provide new evidence that marriage penalties matter. Previous studies may have been limited by problematic identification strategies and/or by applications in which either the penalties are too small to make much of a difference or in which marriage is an institution of decreasing attraction for the affected population. We examine the marriage penalties in the surviving spouse pensions of the Canadian Income Security system. These penalties are monetarily substantial. Also, we focus on reforms - that removed the penalties — which provide a simple and transparent basis for identification.

Our primary contribution is evidence that these marriage penalties had large and persistent effects on the remarriage rates of widows aged 15-59 and prime age widowers. Importantly, the inference is robust to a variety of checks for spurious inference, and varies across age groups and jurisdictions in expected ways.

A secondary contribution, albeit based on small samples, is evidence that suggests the behavior of individuals with characteristics correlated with higher wealth was affected by the penalties. This is perhaps surprising because it is low-income individuals who bear the greater proportionate cost from marriage penalties. We argue, however, that the incremental benefits of marriage over cohabitation may be very small for these individuals. This is because many of the benefits are found in laws covering the treatment of assets and income. 
These results potentially have important welfare implications. The largest and most robust estimated effects are for widowed females under the age of 60. Data (1981 Canadian census) from a year just prior to the reforms reveals that 56 percent of widows in this age group had children at home, so the marriage penalties potentially denied these children any benefits of growing up in a household with married adults. There are also implications for the survivor benefits in the public pension plans of other countries that condition receipt for some widows on the presence of dependent children. The incentives for these beneficiaries match up with the prereform incentives faced by Canadian surviving spouses, with dependent children, who were less than 35 years old. We estimate that the remarriage rates of all widowed females under age 35 increased by between 20 and 40 percent once the marriage penalties were removed. More generally, the results provide a basis for suspicions that marriage penalties in their various manifestations affect behavior. 


\section{References}

Auerbach, Alan J. and Joel Slemrod, "The Economic Effects of the Tax Reform Act of 1986", Journal of Economic Literature, 35, June 1997, 589-632.

Alm, James and Leslie Whittington, “Does the Income Tax Affect Marital Decisions?”, National Tax Journal, 48, December 1995, 361-372.

----------, “The Rise and Fall and Rise...of the Marriage Tax”, National Tax Journal, 49, 1996a, 571-589.

-----------, "Income Taxes and the Timing of Marital Decisions", Journal of Public Economics, 64, 1996b, 219-240.

----------, “For Love or Money? The Impact of Income Taxes on Marriage”, Economica, 66, 1999, 297-316.

Alm, James, Dickert-Conlin, Stacey and Leslie A. Whittington, "Policy Watch: The Marriage Penalty", Journal of Economic Perspectives, 13, Summer 1999, 193-204.

Baker, Michael, "The Retirement Behavior of Married Couples: Evidence From the Spouse's Allowance", Journal of Human Resources, 37, Winter 2002, 1-34.

Baker, Michael and Dwayne Benjamin, "Early Retirement Provisions and the Labor Force Behavior of Older Men: Some Evidence from Canada", Journal of Labor Economics, 17, October 1999, 724-756

Becker, Gary S., “A theory of marriage: Part I”, Journal of Political Economy 81(4), 1973, 813846.

----------, “A theory of marriage: Part II”, Journal of Political Economy 82(2, Part 2), 1974, S11-S26.

Bitler, Marianne, Gelbach, Jonah, Hoynes, Hilary, and Madeline Zavodny, "The Impact of Welfare Reform on Marriage and Divorce", UC-Davis, June 2002.

Blau, Francine D., Kahn, Lawrence M. and Jane Waldfogel, "The Impact of Welfare Benefits on Single Motherhood and Headship of Young Women: Evidence from the Census", National Bureau of Economic Research Working Paper 9338, November 2002.

Brien, Michael J., Dickert-Conlin, Stacy and David A. Weaver, "Widows Waiting to Wed? (Re)Marriage and Economic Incentives in Social Security Widow Benefits", Mimeograph, 2000. 
Bumpass L. and H. Lu, "Trends in Cohabitation and Implications for Children's Family Context in the United States", Population Studies, 54(1), 2000, 29-41.

Burbidge, John, Social Security in Canada: An Economic Appraisal, Canadian Tax Paper No. 79, Toronto: Canadian Tax Foundation, 1987.

CCH Canadian Limited, Canadian Employment benefits and Pension Guide Reports, North York ON: CCH Canadian Limited, 2001.

Canada Pension Plan, Statistical Bulletin, v18 n4, Ottawa: Ministry of National Health and Welfare, 1987.

Corak, Miles, "Death and Divorce: The Long Term Consequences of Parental Loss on Adolescents", Journal of Labor Economics, 19, 2001, 682-715.

Dickert-Conlin, Stacey, "Taxes and Transfers: Their Effects on the Decision to End a Marriage", Journal of Public Economics, 73, 1999, 217-240.

Dickert-Conlin, Stacey and Amitabh Chandra, "Taxes and the Timing of Births", Journal of Political Economy, 107, 1999, 161-177.

Dooley, Martin, Gascon, Stephanne, Lefebvre, Pierre and Phillip Merrigan, "Lone Female Headship and Welfare Policy in Canada", 2001.

Gelardi, Alexander M.G., "The Influence of Tax Law Changes on the Timing of Marriages: A Two-Country Analysis", National Tax Journal, 49, 1996, 17-30.

Grogger Jeff, and Stephen G. Bronars, "The Effect of Welfare Payments on the Marriage and Fertility Behavior of Unwed Mothers: Results from a Twins Experiment", Journal of Political Economy, 109, June 2001, 529-545.

Gruber, Jonathan, "Disability Insurance Benefits and Labour Supply", Journal of Political Economy, 108, December 2000, 1162-1183.

Holland, Winifred H., "Cohabitation : the law in Canada", in W.H. Holland and B.E. Stalbecker (eds.), Cohabitation : the law in Canada, Toronto: Carswell, 1990

Hoynes, Hilary Williamson, "Does Welfare Play any Role in Female Headship Decisions", Journal of Public Economics, 65, 1997, 89-117.

Human Resources Development Canada, Social Security Statistics, Canada and the Provinces, 1970-71 to 1994-95, Ottawa: Minister of Supply and Services Canada, 1994.

Lichter, Daniel T., McLaughlin, Diane K. and David Ribar, "Welfare and the Rise of Female Headed Families", American Journal of Sociology, 102, 1997, 112-143. 
Moffitt, Robert, "Incentive Effects of the US Welfare System: A Review", Journal of Economic Literature, 30, March 1992, 1-61.

Moffitt, Robert, "Welfare Effects on Female Headship with Area Effects", Journal of Human Resources, 29, 1994, 621-636.

Moffitt, Robert, "The Effect of Welfare on Marriage and Fertility", in R. Moffitt (ed.) Welfare, The Family and Reproductive Behavior, Washington D.C.: National Research Council, 1998, 50-97.

Moffitt, R., R. Reville and A.E. Winkler, "Beyond Single Mothers: Cohabitation and Marriage in the AFDC Program", Demography, 35, 1998, 259-278.

Nault, Francois, "Twenty Years of Marriages”, Health Reports, Statistics Canada, Autumn 1996, $39-47$.

Nechyba, Thomas J., "Social Approval, Values and AFDC: A Reexamination of the Illegitimacy Debate", Journal of Political Economy, 109, June 2001, 637-672.

Regie des rentes du Quebec, Statistics Outlook, Quebec: Direction des communications, Regie des rentes du Quebec, 1985.

Sjoquist, David L. and Mary Beth Walker, "The Marriage Tax and the Rate and Timing of Marriage", National Tax Journal, 48, December 1995, 547-558.

Standing Committee on National Health and Welfare, Minutes, $33^{\text {rd }}$ Parliament, $1^{\text {st }}$ Session, March-June 1986, No. 1-7, Ottawa: Supply and Services Canada, 1986.

Statistics Canada, Life Tables, Canada and Provinces:1980-1982, Catalogue 84-532, Statistics Canada, Health Division, Vital Statistics and Disease Registries Section, May 1984.

Solon, Gary., "Estimating Autocorrelations in Fixed-Effects Models" NBER Technical Working Paper \#32, February 1984.

Yelowitz, Aaron S., "Will Extending Medicaid to Two-Parent Families Encourage Marriage?", Journal of Human Resources, 33, 1998, 833-865. 


\section{Appendix:}

Table A1: Parameters of Canada's Income Security Programs in the 1980s

\begin{tabular}{|c|c|c|c|}
\hline & Eligibility and Funding & Benefits & Means/Earnings Tests \\
\hline $\begin{array}{l}\text { Old Age } \\
\text { Security (OAS) }\end{array}$ & $\begin{array}{l}\text { - Age } 65+ \\
\text {-Universal subject to } \\
\text { residency requirement } \\
\text { - Financed from general } \\
\text { tax revenues }\end{array}$ & - Set by Parliament & - None \\
\hline $\begin{array}{l}\text { Guaranteed } \\
\text { Income } \\
\text { Supplement } \\
\text { (GIS) }\end{array}$ & $\begin{array}{l}\text { - Age } 65+ \\
\text { - OAS pensioner } \\
\text { - Satisfy means test } \\
\text { - Financed from general } \\
\text { tax revenues }\end{array}$ & $\begin{array}{l}\text { - Set by Parliament } \\
\text { - Different "Married" } \\
\text { and "Single" benefits. } \\
\text { - Not subject to regular } \\
\text { income taxes }\end{array}$ & $\begin{array}{l}\text { - Yes, based on family } \\
\text { income } \\
\text { - Tax rate of } 50 \%(25 \% \\
\text { if spouse is not a IS } \\
\text { recipient) } \\
\text { - Certain income is } \\
\text { exempt }\end{array}$ \\
\hline $\begin{array}{l}\text { Spouse's } \\
\text { Allowance } \\
\text { (SPA) }\end{array}$ & $\begin{array}{l}\text {-Ages } 60-64 \\
\text {-Spouse is OAS } \\
\text { pensioner or (starting } \\
\text { 1986) individual is } \\
\text { widowed } \\
\text { - Financed from general } \\
\text { tax revenues }\end{array}$ & $\begin{array}{l}\text { - Set by Parliament } \\
\text { - Equivalent to sum of } \\
\text { OAS and relevant GIS } \\
\text { benefits } \\
\text { - Not subject to regular } \\
\text { income taxes }\end{array}$ & $\begin{array}{l}\text { - Yes, based on family } \\
\text { income } \\
\text { - Tax rate of } 75 \% \text { until } \\
\text { OAS component gone } \\
\text { and then like GIS } \\
\text { - Certain income is } \\
\text { exempt }\end{array}$ \\
\hline $\begin{array}{l}\text { Canada/Quebec } \\
\text { Pension Plan } \\
\text { (CPP/QPP) }\end{array}$ & $\begin{array}{l}\text { - QPP: Age 65+ }(1980- \\
\text { 83), Age 60+ }(1984+) \\
\text { - CPP: Age 65+(1980- } \\
\text { 86), Age 60+ }(1987+) \\
\text { - Contribute in at least } \\
\text { one calendar year of } \\
\text { "Contributory Period" } \\
\text { (starts Jan. } 11966 \text { or } \\
\text { age } 18 \text { (whichever is } \\
\text { later) and ends age } 70 \\
\text { or commencement of } \\
\text { pension (whichever is } \\
\text { earlier) } \\
\text { - Financed by } \\
\text { employers' and } \\
\text { employees' } \\
\text { contributions }\end{array}$ & $\begin{array}{l}\text { - } 25 \% \text { of "Average } \\
\text { Pensionable Earnings" } \\
\text { over Contributory } \\
\text { Period up to cap } \\
\text { - Years rearing young } \\
\text { children (as of } 1977 \text { in } \\
\text { QPP or } 1978 \text { in CPP), } \\
\text { receiving a disability } \\
\text { pension and } 15 \text { percent } \\
\text { of remaining years can } \\
\text { be excluded from } \\
\text { calculation } \\
\text { (Contributory Period } \\
\text { cannot be less than } 10 \\
\text { years) } \\
\text {-Benefits subject to } \\
\text { actuarial adjustments } \\
\text { starting } 1984 \text { in QPP } \\
\text { and } 1987 \text { in CPP }\end{array}$ & - None \\
\hline
\end{tabular}


Table A2: Estimates of the Impact of the Marriage Penalties on Remarriage Probabilities Net of Province Specific Quadratic Trends

\begin{tabular}{|c|c|c|c|c|}
\hline & \multicolumn{2}{|c|}{ Widows } & \multicolumn{2}{|c|}{ Widowers } \\
\hline & QU*REF84 & QU*REF87 & QU*REF84 & QU*REF87 \\
\hline \multicolumn{5}{|c|}{ Base Specification } \\
\hline $15-34$ & $\begin{array}{c}0.017 \\
(0.004)\end{array}$ & $\begin{array}{l}-0.019 \\
(0.004)\end{array}$ & $\begin{array}{c}0.068 \\
(0.026)\end{array}$ & $\begin{array}{l}0.063 \\
(0.32)\end{array}$ \\
\hline $35-44$ & $\begin{array}{c}0.011 \\
(0.002)\end{array}$ & $\begin{array}{l}-0.017 \\
(0.003)\end{array}$ & $\begin{array}{c}0.034 \\
(0.015)\end{array}$ & $\begin{array}{c}0.0001 \\
(0.018)\end{array}$ \\
\hline $45-59$ & $\begin{array}{c}0.005 \\
(0.001)\end{array}$ & $\begin{array}{l}-0.006 \\
(0.001)\end{array}$ & $\begin{array}{c}0.014 \\
(0.003)\end{array}$ & $\begin{array}{c}-0.017 \\
(0.003)\end{array}$ \\
\hline $60-64$ & $\begin{array}{c}0.0018 \\
(0.0006)\end{array}$ & $\begin{array}{c}-0.0022 \\
(0.0007)\end{array}$ & $\begin{array}{c}0.003 \\
(0.004)\end{array}$ & $\begin{array}{l}-0.007 \\
(0.005)\end{array}$ \\
\hline $65+$ & $\begin{array}{c}-0.0001 \\
(0.0002)\end{array}$ & $\begin{array}{l}-0.0005 \\
(0.0002)\end{array}$ & $\begin{array}{l}-0.0000 \\
(0.0013)\end{array}$ & $\begin{array}{l}-0.0036 \\
(0.0012)\end{array}$ \\
\hline \multicolumn{5}{|c|}{ Specification Including Timing Effects for 1984 and 1987} \\
\hline $15-34$ & $\begin{array}{c}0.015 \\
(0.005)\end{array}$ & $\begin{array}{l}-0.019 \\
(0.006)\end{array}$ & $\begin{array}{c}0.095 \\
(0.034)\end{array}$ & $\begin{array}{c}0.062 \\
(0.039)\end{array}$ \\
\hline $35-44$ & $\begin{array}{c}0.011 \\
(0.003)\end{array}$ & $\begin{array}{l}-0.013 \\
(0.003)\end{array}$ & $\begin{array}{c}0.050 \\
(0.021)\end{array}$ & $\begin{array}{c}-0.012 \\
(0.022)\end{array}$ \\
\hline $45-59$ & $\begin{array}{c}0.003 \\
(0.001)\end{array}$ & $\begin{array}{c}-0.004 \\
(0.001)\end{array}$ & $\begin{array}{c}0.012 \\
(0.003)\end{array}$ & $\begin{array}{c}-0.020 \\
(0.003)\end{array}$ \\
\hline $60-64$ & $\begin{array}{c}0.0010 \\
(0.0005)\end{array}$ & $\begin{array}{c}-0.0012 \\
(0.0008)\end{array}$ & $\begin{array}{c}-0.001 \\
(0.003)\end{array}$ & $\begin{array}{c}0.003 \\
(0.003)\end{array}$ \\
\hline $65+$ & $\begin{array}{c}-0.0002 \\
(0.0002)\end{array}$ & $\begin{array}{c}-0.0004 \\
(0.0002)\end{array}$ & $\begin{array}{c}-0.0017 \\
(0.0011)\end{array}$ & $\begin{array}{c}-0.0037 \\
(0.0011)\end{array}$ \\
\hline
\end{tabular}

Notes: Source: Vital Statistics and CANSIM data. The sample period is 1975-1995. In addition to the reported parameters, the Base Specification includes a full set of province and year effects, and the sex ratios of unmarried individuals for the age groups 15-34, 15-44, 45-59, 60-64 and $65+$ (see equation (1)) and province specific quadratic trends. The "Timing Effects" are interactions between the dummy variable for Quebec and the year effects for 1984 and 1987, the years the reforms took effect. All estimation by weighted least-squares using the number of widows or widowers in the relevant age group as weights. Standard errors are corrected for heteroskedasticity. 
Table A3: Estimates of the Impact of the Marriage Penalties on Remarriage Probabilities using the Marriage Rates of Singles as a control for Jurisdiction Specific Trends

\begin{tabular}{lcccc}
\hline \multicolumn{3}{c}{ Widows } & \multicolumn{2}{c}{ Widowers } \\
\hline & WID*QU*REF84 & WID*QU*REF87 & WID*QU*REF84 & WID*QU*REF87 \\
\hline Base Specification & 0.023 & -0.006 & 0.052 & -0.004 \\
\hline $15-34$ & $(0.004)$ & $(0.004)$ & $(0.031)$ & $(0.034)$ \\
& 0.015 & -0.006 & 0.020 & -0.001 \\
$35-44$ & $(0.002)$ & $(0.002)$ & $(0.017)$ & $(0.017)$ \\
& 0.006 & -0.005 & 0.011 & -0.015 \\
$45-59$ & $(0.001)$ & $(0.001)$ & $(0.003)$ & $(0.003)$ \\
& 0.0013 & -0.0024 & 0.003 & -0.005 \\
$60-64$ & $(0.0005)$ & $(0.0005)$ & $(0.003)$ & $(0.003)$ \\
& -0.0001 & 0.0010 & -0.004 & 0.0004 \\
$65+$ & $(0.0004)$ & $(0.0004)$ & $(0.002)$ & $(0.002)$ \\
& 0.021 & -0.004 & 0.069 & -0.024 \\
Specification Including Timing Effects for 1984 and 1987 & & $(0.043)$ \\
\hline $15-34$ & $(0.004)$ & $(0.004)$ & $(0.040)$ & -0.003 \\
& 0.015 & -0.012 & 0.029 & $(0.007)$ \\
$35-44$ & $(0.002)$ & $(0.003)$ & $(0.022)$ & -0.013 \\
& 0.005 & -0.004 & 0.009 & $(0.002)$ \\
$45-59$ & $(0.001)$ & $(0.001)$ & $(0.002)$ & -0.0003 \\
& 0.0010 & -0.0022 & -0.001 & $(0.0025)$ \\
$60-64$ & $(0.0005)$ & $(0.0006)$ & $(0.002)$ & 0.002 \\
& -0.0002 & 0.0012 & -0.005 & $(0.002)$ \\
$65+$ & $(0.0004)$ & $(0.0006)$ & $(0.002)$ &
\end{tabular}

Notes: Source: Vital Statistics and CANSIM data. The sample period is 1975-1995. The estimates are based on a pooled sample of marriage rates for widows/widowers and singles. In addition to the reported parameters, the Base Specification includes the variables in equation (1) plus a widow effect (WID) and widow/year, widow/province and province/year effects. The "Timing Effects" are interactions between the dummy variable for Quebec and the year effects for 1984 and 1987, the years the reforms took effect. All estimation by weighted least-squares using the number of widows/widowers or singles in the relevant age group as weights. Standard errors are corrected for heteroskedasticity. 
Table A4: Estimates of the Impact of the Marriage Penalties on Remarriage Probabilities using the Marriage Rates of Divorcees as a control for Jurisdiction Specific Trends

\begin{tabular}{lcccc}
\hline \multicolumn{3}{c}{ Widows } & \multicolumn{2}{c}{ Widowers } \\
\hline & WID*QU*REF84 & WID*QU*REF87 & WID*QU*REF84 & WID*QU*REF87 \\
\hline Base Specification & 0.012 & -0.062 & 0.048 & -0.067 \\
\hline $15-34$ & $(0.015)$ & $(0.016)$ & $(0.024)$ & $(0.032)$ \\
& 0.016 & -0.022 & 0.039 & -0.047 \\
$35-44$ & $(0.003)$ & $(0.003)$ & $(0.024)$ & $(0.026)$ \\
& 0.006 & -0.007 & 0.021 & -0.021 \\
$45-59$ & $(0.001)$ & $(0.001)$ & $(0.003)$ & $(0.004)$ \\
& 0.0018 & -0.0003 & 0.008 & -0.002 \\
$60-64$ & $(0.0016)$ & $(0.0011)$ & $(0.003)$ & $(0.002)$ \\
& 0.0034 & 0.0012 & 0.009 & 0.008 \\
$65+$ & $(0.0024)$ & $(0.0017)$ & $(0.006)$ & $(0.004)$ \\
& -0.0003 & -0.053 & 0.057 & -0.087 \\
Specification Including Timing Effects for 1984 and 1987 & & $(0.039)$ \\
\hline $15-34$ & $(0.0167)$ & $(0.017)$ & $(0.032)$ & -0.065 \\
& 0.015 & -0.022 & 0.051 & $(0.032)$ \\
$35-44$ & $(0.003)$ & $(0.004)$ & $(0.031)$ & -0.024 \\
& 0.005 & -0.006 & 0.021 & $(0.004)$ \\
$45-59$ & $(0.001)$ & $(0.001)$ & $(0.004)$ & -0.0007 \\
& 0.0011 & -0.0002 & 0.007 & $(0.0025)$ \\
$60-64$ & $(0.0018)$ & $(0.0013)$ & $(0.004)$ & 0.005 \\
& 0.0037 & 0.0013 & 0.012 & $(0.004)$ \\
$65+$ & $(0.0029)$ & $(0.0022)$ & $(0.006)$ &
\end{tabular}

Notes: Source: Vital Statistics and CANSIM data. The sample period is 1975-1995. The estimates are based on a pooled sample of marriage rates for widows/widowers and divorcees. In addition to the reported parameters, the Base Specification includes the variables in equation (1) plus a widow effect (WID) and widow/year, widow/province and province/year effects. The "Timing Effects" are interactions between the dummy variable for Quebec and the year effects for 1984 and 1987, the years the reforms took effect. All estimation by weighted least-squares using the number of widows/widowers or divorcees in the relevant age group as weights. Standard errors are corrected for heteroskedasticity. 
Table 1: Monthly Flat Rate Component of Survivor Benefits by Year

\begin{tabular}{|c|c|c|c|}
\hline & \multicolumn{2}{|c|}{ QPP } & CPP \\
\hline 1980 & 146.78 & & 57.25 \\
\hline 1981 & 161.31 & & 62.91 \\
\hline 1982 & 181.18 & & 70.68 \\
\hline \multirow[t]{2}{*}{1983} & 201.44 & & 78.60 \\
\hline & Aged $<55$ & Aged 55-64 & \\
\hline 1984 & 214.94 & 275.00 & 83.87 \\
\hline 1985 & 224.40 & 287.10 & 87.56 \\
\hline 1986 & 233.38 & 298.58 & 91.06 \\
\hline 1987 & 242.95 & 310.82 & 94.79 \\
\hline 1988 & 253.64 & 324.50 & 98.96 \\
\hline 1989 & 264.04 & 337.80 & 103.02 \\
\hline 1990 & 276.71 & 354.01 & 107.96 \\
\hline
\end{tabular}

Notes: All amounts are in current Canadian dollars. Surviving spouses under age 65 receive the flat rate component plus $371 / 2$ percent of the deceased spouse's retirement pension. The benefits for surviving spouses over the age of 64 are described in the text.

Table 2: Average Monthly Benefit of Survivor Pension in Payment in the Month of December Preceding the Removal of the Marriage Penalty

\begin{tabular}{lcccc}
\hline & \multicolumn{2}{c}{ QPP (December 1983) } & \multicolumn{2}{c}{ CPP (December 1986) } \\
\hline Age & Males & Females & Males & Females \\
\hline$<35$ & 445.18 & 484.12 & 254.83 & 301.47 \\
$35-44$ & 411.24 & 466.88 & 219.43 & 285.63 \\
$45-59$ & 436.45 & 498.91 & 248.40 & 314.94 \\
$60-64$ & 447.64 & 497.78 & 237.61 & 309.77 \\
$65-69$ & 74.02 & 219.64 & 63.62 & 214.25 \\
\hline
\end{tabular}

Notes: All amounts are in year 2001 Canadian dollars. Source Regie des rentes du Quebec (1985) and Canada Pension Plan (1987). 
Table 3: The Simple Present Value of the Average Monthly Benefit of Survivor Pensions in Payment in the Month of December Preceding the Removal of the Marriage Penalty

\begin{tabular}{lcccc}
\hline & \multicolumn{2}{c}{ QPP } & Males & CPP \\
\hline Age & Males & Females & 31231 & 36947 \\
\hline 30 & 54527 & 61821 & 61713 & 80359 \\
40 & 115629 & 131235 & 60197 & 76322 \\
50 & 105710 & 120839 & 46710 & 60896 \\
60 & 87949 & 97802 & 10912 & 36748 \\
65 & 12689 & 37649 & & \\
\hline
\end{tabular}

Notes: All amounts are in year 2001 Canadian dollars. Average monthly benefits are taken from table 2. Individuals under age 45 are assumed to have children so there is no reduction in benefits. Individuals aged 30 are assumed to have one child aged 5 who finishes school at age 18 , so benefits are received for 13 years.

Table 4: Proportion of Widows Receiving QPP or CPP Survivor Benefits

\begin{tabular}{lcccccccccc}
\hline \multicolumn{1}{c}{ Females } \\
\hline Age & $<35$ & $35-44$ & $45-59$ & $60-64$ & $65+$ & $<35$ & $35-44$ & $45-59$ & $60-64$ & $65+$ \\
\hline \multicolumn{1}{l}{ Quebec in Years Preceding the 1984 Reform } \\
\hline 1981 & 0.71 & 0.79 & 0.68 & 0.58 & 0.27 & 0.24 & 0.37 & 0.19 & 0.13 & 0.05 \\
1982 & 0.71 & 0.87 & 0.71 & 0.61 & 0.31 & 0.23 & 0.45 & 0.22 & 0.14 & 0.06 \\
1983 & 0.71 & 0.89 & 0.74 & 0.64 & 0.35 & 0.23 & 0.52 & 0.24 & 0.16 & 0.07 \\
\hline \multicolumn{1}{l}{ The ROC in Years Preceding the 1987 Reform } \\
\hline 1984 & 0.67 & 0.89 & 0.83 & 0.65 & 0.33 & 0.17 & 0.40 & 0.36 & 0.26 & 0.12 \\
1985 & 0.67 & 0.90 & 0.85 & 0.66 & 0.37 & 0.16 & 0.40 & 0.36 & 0.27 & 0.14 \\
1986 & 0.66 & 0.92 & 0.87 & 0.68 & 0.39 & 0.16 & 0.37 & 0.38 & 0.30 & 0.16 \\
\hline
\end{tabular}

Notes: Source Statistics Canada's CANSIM database, Source Regie des rentes du Quebec (1985) and Canada Pension Plan (1987). 
Table 5: Some Characteristics of Widows and Widowers from the 1981 Canadian Census

\begin{tabular}{lcccc}
\hline & \multicolumn{2}{c}{ Widows } & \multicolumn{2}{c}{ Widowers } \\
\hline & Quebec & ROC & Quebec & ROC \\
\hline All Ages (16+) & & & & \\
\hline Age & 67.6 & 68.8 & 69.3 & 70.9 \\
Employed & 0.13 & 0.17 & 0.26 & 0.26 \\
High School Graduate & 0.10 & 0.06 & 0.07 & 0.04 \\
University Graduate & 0.01 & 0.02 & 0.02 & 0.04 \\
Wages if employed & 8975 & 8432 & 12673 & 13439 \\
Total Income (all individuals) & 6573 & 7557 & 8933 & 10574 \\
Cross Jurisdictional Mover in Past & 0.004 & 0.006 & 0.004 & 0.005 \\
5 years & & & & 3023 \\
Sample Size & 4794 & 14464 & 1006 & \\
\hline Ages 16-59 & & & & 50.4 \\
\hline Age & 50.9 & 50.7 & 51.0 & 0.77 \\
Employed & 0.38 & 0.55 & 0.73 & 0.05 \\
High School Graduate & 0.13 & 0.10 & 0.12 & 0.07 \\
University Graduate & 0.02 & 0.03 & 0.03 & 16816 \\
Wages if employed & 9623 & 9396 & 14336 & 17926 \\
Total Income (all individuals) & 8538 & 10477 & 14093 & 0.006 \\
Cross Jurisdictional Mover in Past & 0.008 & 0.006 & 0.005 & 535 \\
5 years & 1122 & 2630 & 214 & \\
Sample Size & & & & \\
\hline
\end{tabular}

Notes: Source 1981 Canadian Census. 
Table 6: Estimates of the Impact of the Marriage Penalties on Remarriage Probabilities

\begin{tabular}{|c|c|c|c|c|}
\hline & \multicolumn{2}{|c|}{ Widows } & \multicolumn{2}{|c|}{ Widowers } \\
\hline & QU*REF84 & QU*REF87 & QU*REF84 & QU*REF87 \\
\hline \multicolumn{5}{|c|}{ Base Specification } \\
\hline $15-34$ & $\begin{array}{c}0.016 \\
(0.003) \\
{[0.42]}\end{array}$ & $\begin{array}{l}-0.017 \\
(0.004) \\
{[-0.24]}\end{array}$ & $\begin{array}{c}0.056 \\
(0.022) \\
{[0.70]}\end{array}$ & $\begin{array}{l}-0.001 \\
(0.026) \\
{[-0.01]}\end{array}$ \\
\hline $35-44$ & $\begin{array}{c}0.013 \\
(0.002) \\
{[1.00]}\end{array}$ & $\begin{array}{l}-0.009 \\
(0.002) \\
{[-0.24]}\end{array}$ & $\begin{array}{c}0.025 \\
(0.015) \\
{[0.43]}\end{array}$ & $\begin{array}{c}0.010 \\
(0.016) \\
{[0.10]}\end{array}$ \\
\hline $45-59$ & $\begin{array}{c}0.007 \\
(0.001) \\
{[1.00]}\end{array}$ & $\begin{array}{l}-0.005 \\
(0.001) \\
{[-0.38]}\end{array}$ & $\begin{array}{c}0.018 \\
(0.002) \\
{[0.55]}\end{array}$ & $\begin{array}{l}-0.013 \\
(0.002) \\
{[-0.22]}\end{array}$ \\
\hline $60-64$ & $\begin{array}{c}0.0015 \\
(0.0004) \\
{[0.28]}\end{array}$ & $\begin{array}{c}-0.0028 \\
(0.0005) \\
{[-0.44]}\end{array}$ & $\begin{array}{c}0.003 \\
(0.003) \\
{[0.10]}\end{array}$ & $\begin{array}{l}-0.005 \\
(0.003) \\
{[-0.12]}\end{array}$ \\
\hline $65+$ & $\begin{array}{c}-0.0002 \\
(0.0001) \\
{[-0.10]}\end{array}$ & $\begin{array}{c}-0.0006 \\
(0.0001) \\
{[-0.32]}\end{array}$ & $\begin{array}{c}-0.0005 \\
(0.0010) \\
{[-0.04]}\end{array}$ & $\begin{array}{c}-0.0036 \\
(0.0010) \\
{[-0.26]}\end{array}$ \\
\hline \multicolumn{5}{|c|}{ Specification Including Timing Effects for 1984 and 1987} \\
\hline $15-34$ & $\begin{array}{c}0.014 \\
(0.004) \\
{[0.37]}\end{array}$ & $\begin{array}{l}-0.015 \\
(0.004) \\
{[-0.21]}\end{array}$ & $\begin{array}{c}0.074 \\
(0.029) \\
{[0.94]}\end{array}$ & $\begin{array}{l}-0.023 \\
(0.032) \\
{[-0.23]}\end{array}$ \\
\hline $35-44$ & $\begin{array}{c}0.014 \\
(0.002) \\
{[1.08]}\end{array}$ & $\begin{array}{l}-0.008 \\
(0.002) \\
{[-0.22]}\end{array}$ & $\begin{array}{c}0.039 \\
(0.019) \\
{[0.67]}\end{array}$ & $\begin{array}{l}-0.001 \\
(0.019) \\
{[-0.06]}\end{array}$ \\
\hline $45-59$ & $\begin{array}{c}0.005 \\
(0.001) \\
{[0.71]}\end{array}$ & $\begin{array}{l}-0.004 \\
(0.001) \\
{[-0.31]}\end{array}$ & $\begin{array}{c}0.017 \\
(0.003) \\
{[0.52]}\end{array}$ & $\begin{array}{l}-0.012 \\
(0.003) \\
{[-0.20]}\end{array}$ \\
\hline $60-64$ & $\begin{array}{c}0.0009 \\
(0.0003) \\
{[0.17]}\end{array}$ & $\begin{array}{c}-0.0020 \\
(0.0004) \\
{[-0.31]}\end{array}$ & $\begin{array}{c}-0.0006 \\
(0.0018) \\
{[-0.02]}\end{array}$ & $\begin{array}{c}0.0008 \\
(0.0016) \\
{[-0.02]}\end{array}$ \\
\hline $65+$ & $\begin{array}{c}-0.0003 \\
(0.0001) \\
{[-0.15]}\end{array}$ & $\begin{array}{c}-0.0003 \\
(0.0001) \\
{[-0.16]}\end{array}$ & $\begin{array}{c}-0.0018 \\
(0.0008) \\
{[-0.13]}\end{array}$ & $\begin{array}{c}-0.0026 \\
(0.0007) \\
{[-0.19]}\end{array}$ \\
\hline
\end{tabular}

Notes: Source: Vital Statistics and CANSIM data. The sample period is 1975-1995. In addition to the reported parameters, the Base Specification includes a full set of province and year effects, and the sex ratios of unmarried individuals for the age groups 15-34, 15-44, 45-59, 60-64 and $65+$ (see equation (1)). The "Timing Effects" are interactions between the dummy variable for Quebec and the year effects for 1984 and 1987, the years the reforms took effect. All estimation by weighted least-squares using the number of widows or widowers in the relevant age group as weights. Standard errors are corrected for heteroskedasticity. 
Table 7: Estimates of the Impact of the Marriage Penalties on the Stock of Widows

\begin{tabular}{lcccc}
\hline \multicolumn{2}{c}{ Widows } & \multicolumn{2}{c}{ Widowers } \\
\hline \multicolumn{2}{c}{ QU*REF84 } & QU*REF87 & QU*REF84 & QU*REF87 \\
\hline Base Specification & & -0.0000 & -0.0006 \\
\multirow{3}{*}{$35-44$} & -0.0008 & -0.0001 & $(0.0004)$ & $(0.0004)$ \\
& $(0.0005)$ & $(0.0005)$ & -0.0014 & 0.0008 \\
$45-59$ & 0.0002 & -0.0049 & $(0.0011)$ & $(0.0010)$ \\
& $(0.0021)$ & $(0.0020)$ & -0.0053 & 0.0017 \\
$60-64$ & 0.0033 & -0.0029 & $(0.0022)$ & $(0.0021)$ \\
& $(0.0042)$ & $(0.0042)$ & -0.0042 & 0.0041 \\
$65+$ & -0.0006 & 0.0109 & $(0.0065)$ & $(0.0065)$ \\
& $(0.0115)$ & $(0.0117)$ & 0.0236 & -0.0144 \\
& 0.0033 & 0.0232 & $(0.0074)$ & $(0.0075)$ \\
\hline
\end{tabular}

Notes: Source: Labor Force Survey and CANSIM data. The sample period is 1975-1995. In addition to the reported parameters, the estimating equation includes a full set of province and year effects, and the sex ratios of unmarried individuals for the age groups 15-34, 15-44, 45-59, 60-64 and 65+ (see equation (1)). All estimation by weighted least-squares using LFS sample weights. Standard errors are corrected for heteroskedasticity. 
Table 8: Evidence of the Widows and Widowers Who Responded to the Removal of the Marriage Penalties drawn from the 1990 and 1995 General Social Surveys

\begin{tabular}{|c|c|c|}
\hline \multicolumn{3}{|l|}{ Sample Characteristics } \\
\hline \multicolumn{2}{|l|}{ Sample Size } & 2179 \\
\hline \multicolumn{2}{|l|}{ Age at Death of Spouse } & 59 \\
\hline \multicolumn{2}{|l|}{ Elementary Education } & 0.37 \\
\hline \multicolumn{2}{|l|}{ University Graduate } & 0.13 \\
\hline \multicolumn{2}{|l|}{ Resident in Quebec } & 0.25 \\
\hline \multicolumn{2}{|l|}{ Remarried in Sample Period } & 0.12 \\
\hline 1995 survey & & 0.55 \\
\hline \multicolumn{3}{|c|}{ Regression Results for Full Sample } \\
\hline & QU*REF84 & QU*REF87 \\
\hline \multirow[t]{2}{*}{ Elementary Education } & -0.441 & 0.156 \\
\hline & $(0.111)$ & $(0.232)$ \\
\hline \multirow[t]{2}{*}{ High School Graduate } & 0.423 & -0.302 \\
\hline & $(0.319)$ & $(0.385)$ \\
\hline \multirow[t]{2}{*}{ Post Secondary Education } & 0.149 & -0.076 \\
\hline & $(0.349)$ & $(0.402)$ \\
\hline \multirow[t]{2}{*}{ University Graduate } & 0.275 & -0.118 \\
\hline & $(0.329)$ & $(0.374)$ \\
\hline Household Member Owns & 0.180 & -0.169 \\
\hline Dwelling & $(0.310)$ & $(0.368)$ \\
\hline Cohabitated Prior to & 0.310 & -0.474 \\
\hline Remarriage & $(0.299)$ & $(0.301)$ \\
\hline \multicolumn{3}{|c|}{ Regression Results for Females } \\
\hline \multirow[t]{2}{*}{ Elementary Education } & -0.460 & -0.022 \\
\hline & $(0.096)$ & $(0.089)$ \\
\hline \multirow[t]{2}{*}{ High School Graduate } & 0.758 & -0.844 \\
\hline & $(0.111)$ & $(0.132)$ \\
\hline \multirow[t]{2}{*}{ Post Secondary Education } & 0.378 & -0.446 \\
\hline & $(0.335)$ & $(0.344)$ \\
\hline \multirow[t]{2}{*}{ University Graduate } & 0.475 & -0.377 \\
\hline & $(0.379)$ & $(0.379)$ \\
\hline Household Member Owns & 0.628 & -0.842 \\
\hline Dwelling & $(0.112)$ & $(0.118)$ \\
\hline Cohabitated Prior to & 0.389 & -0.692 \\
\hline Remarriage & $(0.361)$ & $(0.372)$ \\
\hline
\end{tabular}

Notes: Source 1990 and 1995 General Social Survey. In addition to the reported parameters, the regression equation includes quartics in age, age at spouse's death, the year the spouse died and the year of any remarriage, and dummy variables for Quebec, remarriage and females (where appropriate). All estimation by weighted least-squares using GSS sample weights. Standard errors are corrected for heteroskedasticity. 
Figure 1: Marriage rates by Marital Status in Canada, 1974-1994

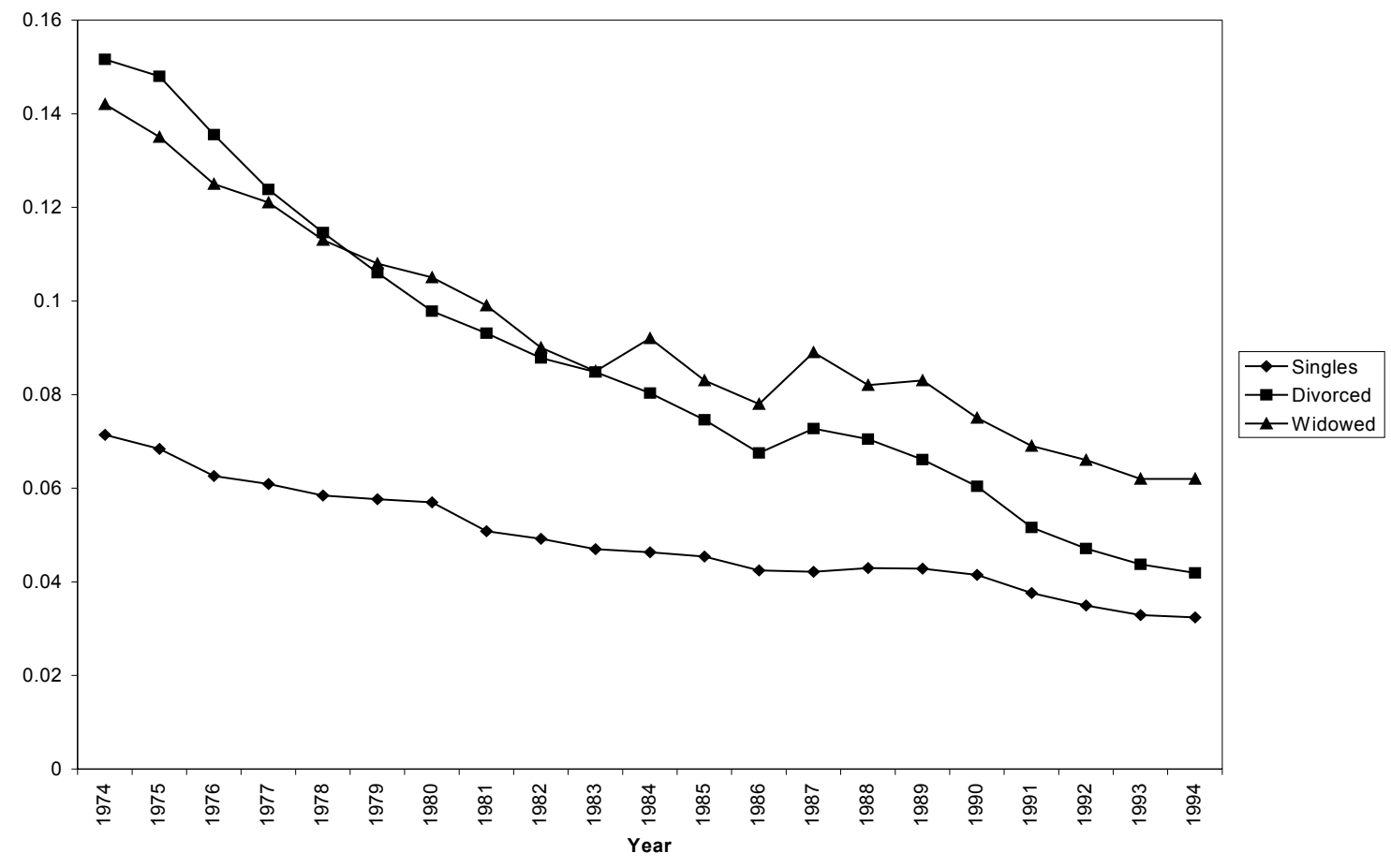

Notes: Source Nault (1996). The rates for the widowed population have been multiplied by 10 to produce a common scale.

Figure 2: Growth Rates of CPP/QPP Survivor Pension Beneficiaries

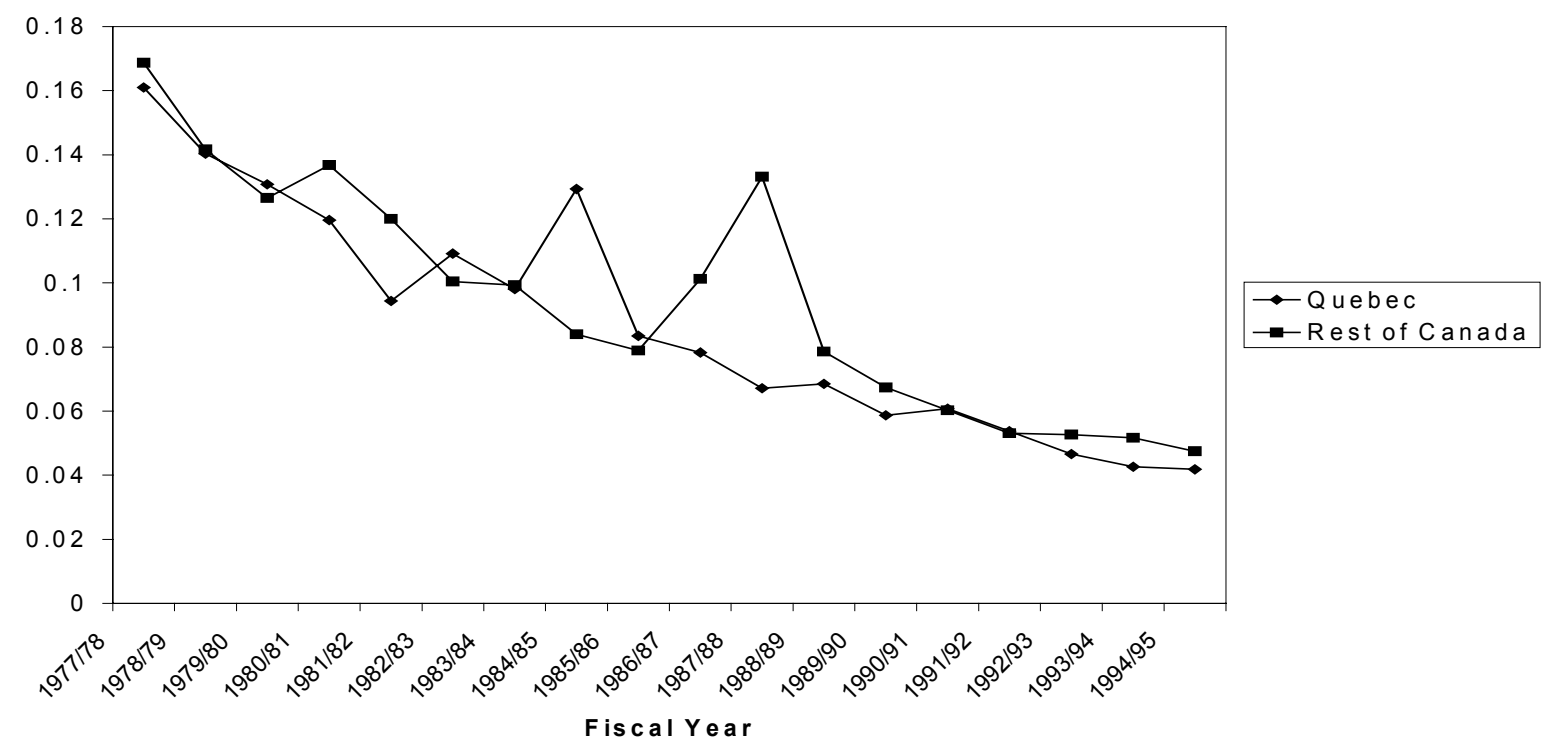

Notes: Source Human Resources Development Canada (1994). 
Figure 3: Remarriage Rates of Widows and Widowers, 1956-1975

Widows

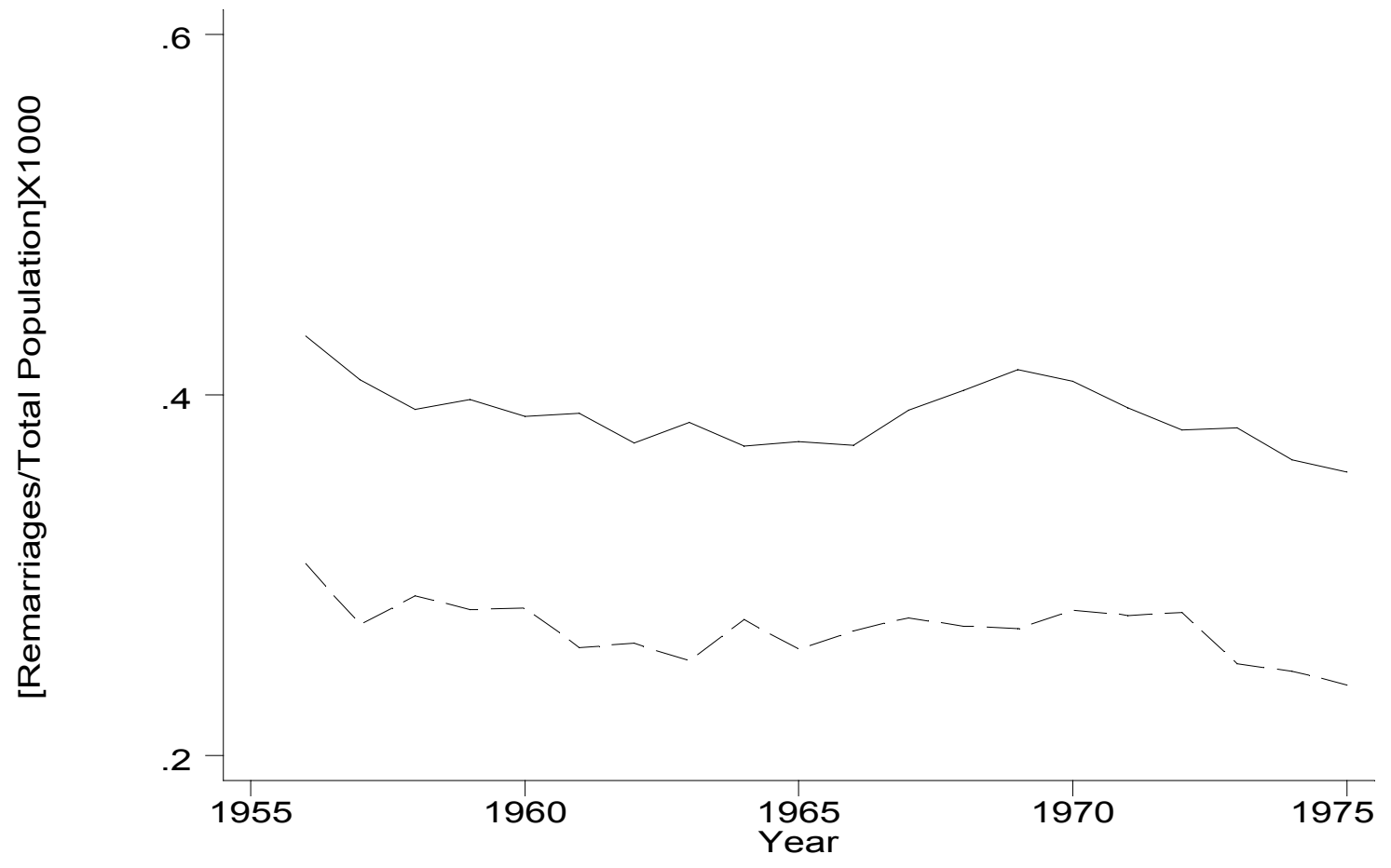

Widowers

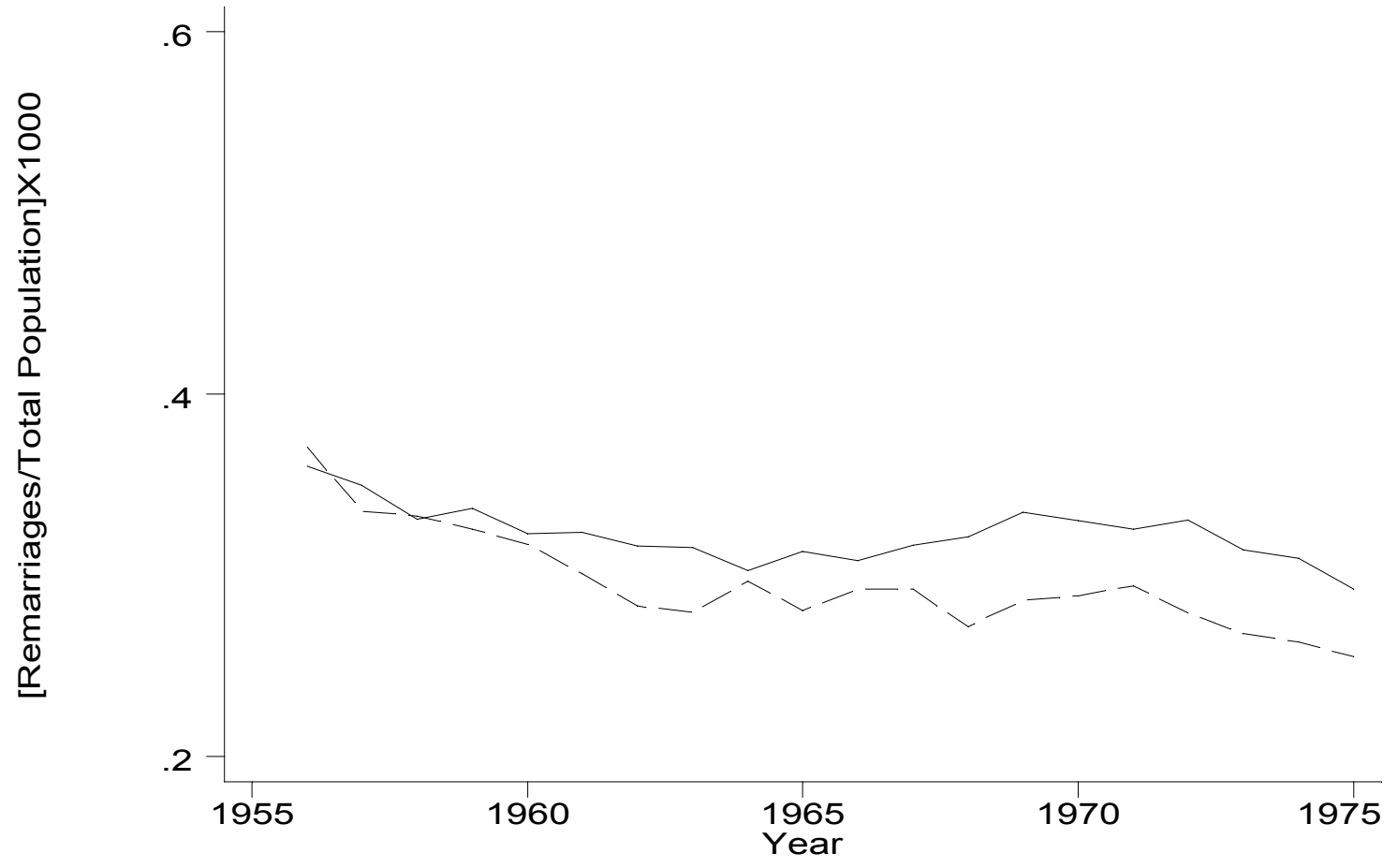

Notes: Quebec ---------, Rest of Canada - 
Figure 4: Remarriage Rates of Widows in Quebec and the Rest of Canada, 1975-1995


Notes: Quebec ---------, Rest of Canada 
Figure 5: Remarriage Rates of Widowers in Quebec and the Rest of Canada, 1975-1995
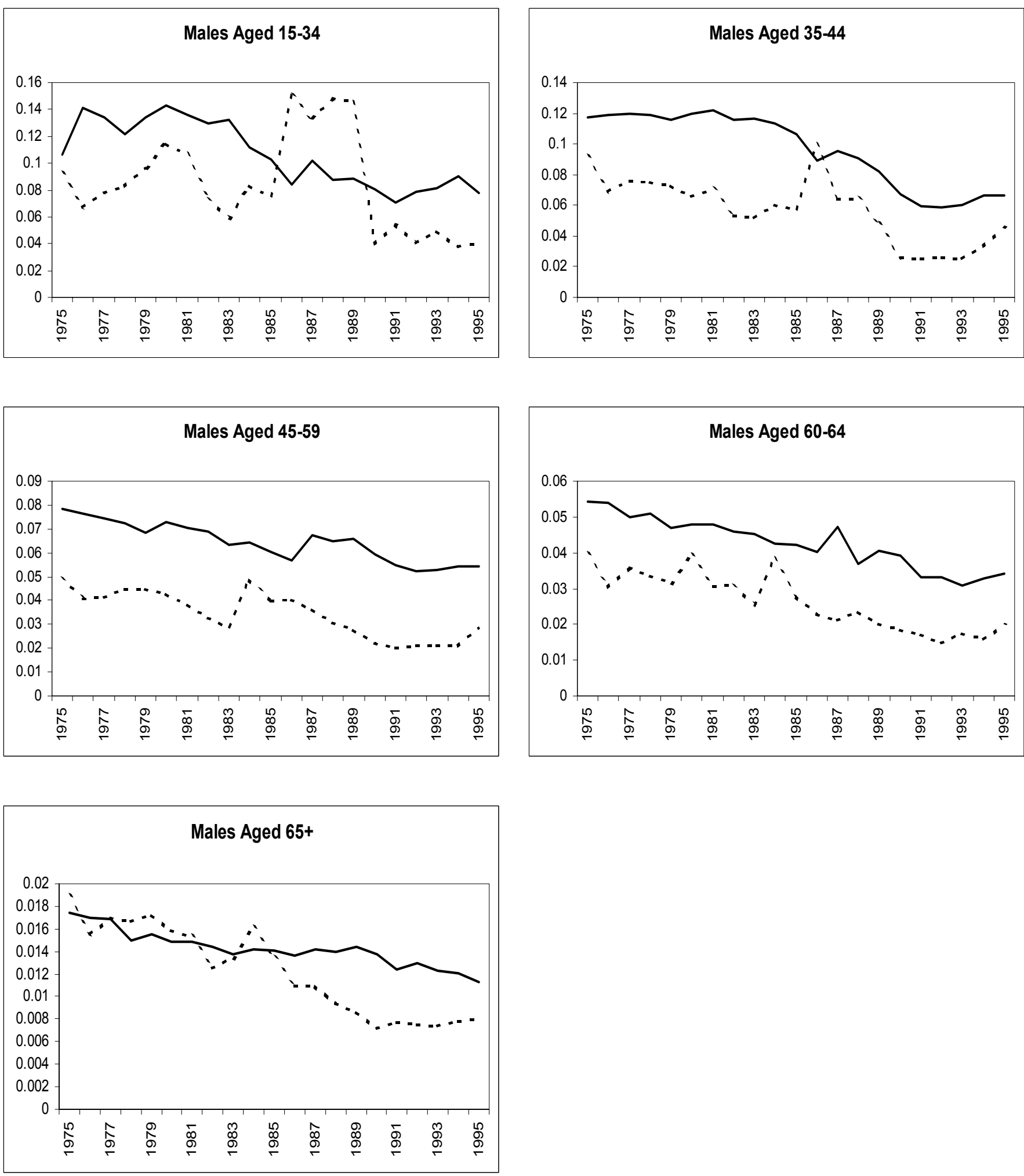

Notes: Quebec Rest of Canada 
Figure 6: The Relationship Between the Estimated Behavioral Response and the Size of the Marriage Penalty

Panel A

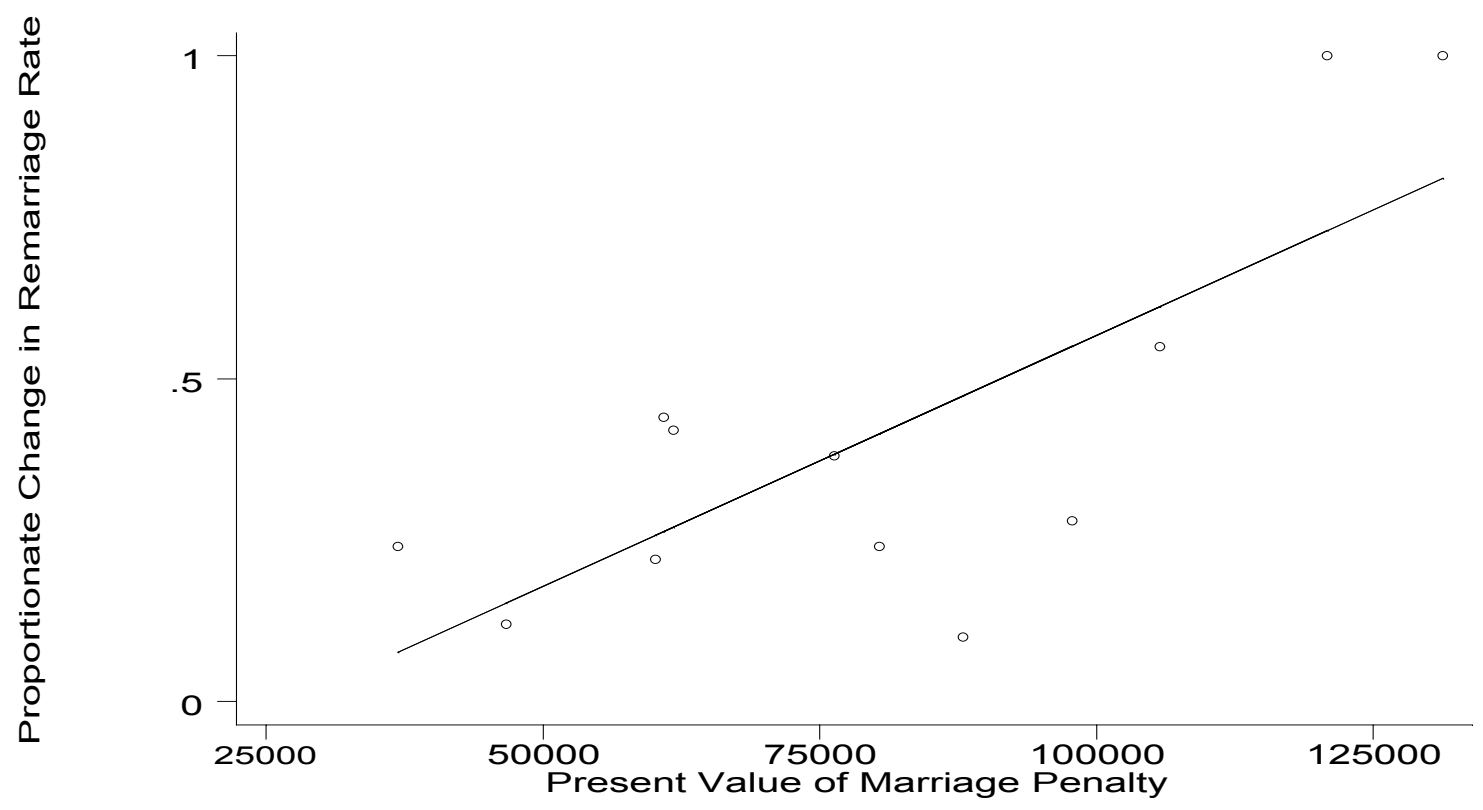

\section{Panel B}

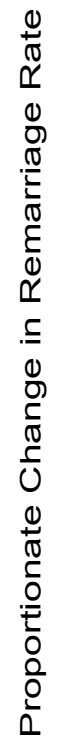



Notes: In panel A the present values of marriage penalties and estimated behavioral responses are from tables 3 and 6 respectively. In the panel B the estimated behavioral responses have been divided by the proportion of widow(er)s in an age group receiving a survivor pension from table 4, to account for differences in treatment across age groups. The solid lines graph the predicted values of the simple regression of the behavioral responses on the marriage penalties. 